Davi Roncoletta Nascimento

Respostas de CAM às variações ambientais na bromélia Dyckia tuberosa (Vellozo) Beer

Versão corrigida. Original disponível no Instituto de Biociências da USP

São Paulo

2012 


\section{Respostas de CAM às variações ambientais na bromélia Dyckia tuberosa (Vellozo) Beer}

Versão corrigida. Original disponível no Instituto de Biociências da USP

Dissertação apresentada ao Instituto de

Biociências da Universidade de São Paulo, para obtenção de título de Mestre em

Ciências, na área de Ecologia.

Orientador: Prof. Dr. Sergio Tadeu Meirelles

São Paulo 


\section{Ficha Catalográfica}

Davi Roncoletta Nascimento

Respostas de CAM às variações ambientais na bromélia

Dyckia tuberosa (Vellozo) Beer

Número de páginas: 58

Dissertação (Mestrado) - Instituto de Biociências da Universidade de São Paulo. Departamento de Ecologia.

1. Metabolismo Ácido Crassuláceo, 2. Afloramento

Rochoso, 3.Ecofisiologia Vegetal.

I. Universidade de São Paulo. Instituto de Biociências.

Departamento de Ecologia.

Comissão Julgadora

Prof. $\left({ }^{a}\right)$. Dr. $\left({ }^{a}\right)$.

Prof. $\left({ }^{a}\right)$. Dr. $\left({ }^{a}\right)$.

Prof. Dr. Sergio Tadeu Meirelles 
Dedicatória

Aos meus ancestrais Aos meus mestres 
ÍNDICE

Resumo

Abstract

02

Introdução

03

Materiais e Métodos

Resultados

25

Discussão

41

Considerações Finais

52

Referências

53 


\section{RESUMO}

Plantas com o tipo fotossintético CAM podem suportar condições de baixa disponibilidade de água através de um sistema de concentração de gás carbônico que aumenta a eficiência de uso da água através de uma fixação inicial do $\mathrm{CO}_{2}$ durante a noite, em condições de baixo déficit de pressão de vapor entre a folha e a atmosfera. Esse processo favorece a ocupação de regiões áridas e de sítios onde a água pode se tornar rapidamente indisponível. A ocorrência desse tipo fotossintético abrange uma grande amplitude de táxons, incluindo a família Bromeliaceae. Entre as espécies de Bromeliaceae que apresentam CAM encontra-se Dickya tuberosa, uma espécie que apresenta uma grande abundância nos afloramentos rochosos associados ao monumento natural da Pedra Grande - Atibaia - SP. Nesse local, D. tuberosa apresenta um papel relevante na vegetação associada à superfície de rocha exposta como componente essencial das comunidades denominadas "ilhas de vegetação". As condições predominantes no afloramento rochoso da Pedra Grande são de grande escassez de solo e água, além de extrema exposição. As variações na disponibilidade de água no afloramento rochoso seriam devidas, entre outras causas, ao tamanho das ilhas de vegetação onde $D$. tuberosa ocorre e às características de declividade e orientação da vertente da superfície rochosa onde a ilha está instalada. A partir das observações no ambiente natural, pergunta-se se os padrões de assimilação em $D$. tuberosa relacionados ao CAM apresentam variações associadas às características das ilhas de solo onde ocorre. Para investigar esta relação, plantas de $D$. tuberosa foram estudadas em campo e em condições semi-controladas em casa de vegetação. A técnica utilizada para caracterização dos padrões de CAM foi a titulação da acidez do mesofilo. Tanto em grupos experimentais submetidos a períodos distintos de suspensão da rega como em amostras obtidas diretamente do campo, observam-se padrões de variação da acidez que podem ser associados à variações no suprimento hídrico. As variações foram caracterizadas através da diferença na acidez entre o início da manhã e o final da tarde. A redução na amplitude da variação coincidiu com a intensidade da restrição no suprimento hídrico. Entretanto, a variação foi associada à redução do valor da acidez no final do dia, o que estaria associado a uma redução na recaptura do $\mathrm{CO}_{2}$ durante o período de iluminação. $A$ maior influência detectada nas plantas em campo foi a umidade relativa do ar. Conjectura-se um papel da assimilação de água através das folhas de $D$. tuberosa como um atributo essencial à ocupação do substrato rochoso na Pedra Grande - Atibaia. 


\section{ABSTRACT}

Plants with crassulacean acid metabolism are able to support conditions of low availability of water through a carbon dioxide concentration system which increases the efficiency of use of water through an overnight $\mathrm{CO}_{2}$ fixture under low deficit of vapor pressure between the leaf and the atmosphere. This process favors the occupation of arid regions and places where water can quickly become unavailable. The occurrence of this type photosynthetic covers a wide range of taxa, including the Bromeliaceae family. Among the species of Bromeliaceae presenting CAM is Dickya tuberosa, a species that has a great abundance on rocky outcrops associated with natural monument of Pedra Grande - Atibaia - SP. At this site, D. tuberosa has a role in vegetation associated with surface rock exposed as an essential component of communities called "vegetation islands". The conditions prevailing in the rocky outcrop of Pedra Grande are of great scarcity of land and water, and extreme exposure. The variations in water availability in rocky outcrop would be due, among other reasons, the size of the islands where vegetation $D$. tuberosa occurs and the characteristics of inclination and orientation of the slope of the rocky surface where the island is installed. From the observations in the natural environment, wonders whether the patterns of assimilation in $D$. tuberosa related to CAM presents variations associated characteristics of vegetation islands where it occurs. To investigate this relationship, plants of $D$. tuberosa were studied in field and semi-controlled conditions in a greenhouse. The technique used to characterize patterns of CAM was the titration acidity of the mesophyll. In both experimental groups undergoing different periods of suspension of irrigation as in samples obtained directly from the field, there are patterns of variation in acidity that may be associated with variations in water supply. The changes were characterized by the difference in acidity between the early morning and late afternoon. The reduction in amplitude of the variation coincided with the intensity of the restriction in water supply. However, the variation was associated with reduced acidity value at the end of the day, which would be associated with a reduction in the recapture of $\mathrm{CO}_{2}$ during the illumination period. The major influence detected on plants in the field was the relative humidity. It is conjectured a part of the assimilation of water through the leaves of $D$. tuberosa as an essential attribute of the occupation of substrate in Pedra Grande - Atibaia. 


\section{Introdução}

A capacidade de ocupar um ambiente é determinada pelas características fisiológicas de cada ser vivo e a capacidade de competir com outros organismos vivos que pretendem ocupar aquele ambiente. O organismo deve ser capaz de utilizar com mais eficiência os recursos do ambiente para superar seu competidor e ter sucesso na ocupação do ambiente. Nas plantas o recurso ambiental que esta entre os mais passíveis de ser objeto da competição é a água.

A ocupação do ambiente terrestre pelas plantas depende, em grande parte, de sua capacidade de resistir ao déficit hídrico, pois o equilíbrio entre o tecido vegetal e a atmosfera geralmente produz a morte da planta. Dessa forma, barreiras eficazes entre o conteúdo de água da planta e o meio onde ela se encontra são necessárias para o estabelecimento e desenvolvimento. Entretanto, a assimilação de $\mathrm{CO}_{2}$ envolve uma via de fluxo por onde a água é perdida, sendo a molécula de água menor do que a de $\mathrm{CO}_{2}$, uma via necessária para a difusão de uma molécula de gás carbônico envolve a perda de água por difusão.

A eficiência de uso da água $\left(\mathrm{CO}_{2}\right.$ fixado $/ \mathrm{H}_{2} \mathrm{O}$ transpirado) pelas plantas influencia na capacidade de ocupar ambientes caracterizados pela baixa disponibilidade hídrica. Baixa pluviosidade, como em climas áridos, ou pequeno volume de substrato, como no habitat epifítico, caracterizam ambientes xéricos, ocupados por plantas capazes de suportar longos períodos de estresse hídrico. Uma estratégia comum em plantas sob estresse hídrico é fechar os estômatos durante o dia para evitar a perda de água. No tipo mais comum de sistema fotossintético, chamado de C3 por ser o primeiro produto da fixação do 
gás carbônico atmosférico um ácido de três carbonos, a resposta típica ao estresse hídrico é o fechamento estomático. Essa resposta implica na paralisação da fotossíntese pela falta de $\mathrm{CO}_{2}$, mas ficar alguns dias sem realizar fotossíntese pode danificar permanentemente o metabolismo da planta, levando à morte.

Em um grupo de plantas a fotossíntese ocorre com os estômatos fechados durante o dia através de um mecanismo de armazenamento de carbono. São as plantas com metabolismo ácido crassuláceo (CAM, do inglês, Crassulacean Acid Metabolism). Com os estômatos abertos durante a noite, as plantas CAM fixam $\mathrm{CO}_{2}$ atmosférico pela ação da enzima fosfoenolpiruvato carboxilase (PEPC) (Cushman \& Bohnert, 1997), culminando na síntese de malato, que é acumulado como ácido málico nos vacúolos de células fotossintetizantes até o inicio do dia, quando a descarboxilação libera $\mathrm{CO}_{2}$ nos espaços intercelulares para assimilação fotossintética via ciclo de Calvin (Chen et al., 2002), como no tipo C3 de fotossíntese. As plantas CAM podem isolar seus tecidos da atmosfera durante o dia, evitando a perda de água para a atmosfera, enquanto fazem fotossíntese. A abertura noturna dos estômatos diminui a perda de água, uma vez que durante a noite as pressões de evapotranspiração são menores por conta da menor temperatura e maior umidade relativa do ar (Cushman \& Bohnert, 1997).

O tipo CAM de fotossíntese é derivado do tipo C3 de fotossíntese pelo incremento da expressão de genes envolvidos em produção e transporte de ácidos C4 (Taybi et al., 2004), mas a origem do CAM é mal compreendida (Crayn et al., 2004). Em Bromeliaceae, por exemplo, a aridez progressiva e o declínio das concentrações de $\mathrm{CO}_{2}$ durante o Terciário favoreceram o surgimento da fotossíntese tipo CAM (Pearson \& Palmer, 2000). O tipo CAM de fotossíntese é altamente dispersado taxonomicamente (Crayn et al., 2004), presente em 7\% das espécies vegetais, em 34 famílias (Holtum et al., 2007), 328 gêneros 
(Winter \& Smith, 1996) e 16000 espécies (Crayn et al., 2004), incluindo monocotiledôneas, dicotiledôneas e pteridófitas (Reinert et al., 2003). Em cada família, os táxons mais primitivos geralmente não apresentavam assimilação noturna de $\mathrm{CO}_{2}$ nem acidificação noturna, enquanto os grupos mais derivados exibiam esse sistema (Williams, 1970), mas em bromélias o tipo fotossintético C3 pode ter aparecido secundariamente a partir de plantas CAM (Reinert et al., 2003). A hipótese de uma origem monofilética de CAM foi rejeitada (Crayn et al., 2004), mas ainda continuam inconclusivos os eventos evolutivos e ambientais que levaram um processo bioquímico complexo como o CAM a ser selecionado positivamente tantas vezes na história evolutiva das plantas (Reinert et al., 2003).

Os padrões de abertura dos estômatos em plantas CAM foram classificados por Osmond (1978) em quatro fases e podem ser definido de acordo com a atividade das enzimas de fixação de carbono. A fixação de carbono atmosférico, denominada primária, ocorre via PEPC no escuro ou com pouca luz e via RubiscoC quando a planta está com os estômatos abertos. A fixação do carbono liberado pelo malato, denominada secundária, ocorre via RubiscoC quando a planta esta com os estômatos fechados durante o dia. A fase I ocorre durante a noite, onde a fixação é feita pelo PEPC. A fase II começa com o nascer do Sol pode durar até 3 horas (Borland et al., 1993), quando PEPC e RubiscoC atuam concomitantemente durante uma transição gradual de PEPC para RubiscoC (Borland \& Griffiths, 1996), gerando um pico de fixação de carbono. A fase III ocorre durante a maior do período diurno, onde apenas RubiscoC é funcional e a fase IV é no final da tarde, quando PEPC e RubiscoC novamente atuam no mesmo momento.

Plantas com manifestação de diferentes tipos de CAM têm diferentes potencialidades de explorar tais fases para a fixação de $\mathrm{CO}_{2}$, variando de espécies que parecem plantas C3 para aquelas que exibem CAM obrigatório (Cushman \& Bohnert, 
1997). A abertura estomática e, consequentemente, a assimilação de carbono e a transpiração devem ocorrer de forma que a planta perca o menor volume possível de água. Plantas CAM podem modificar o período do ciclo circadiano em que irão abrir os estômatos, sendo sensíveis ao meio externo, alternando entre vias metabólicas de fixação de carbono de acordo com a variação das condições ambiente (Black, 1973).

Para definir o tipo de CAM que a planta esta utilizando, a medição de malato ao longo do ciclo circadiano é o suficiente. Outra forma é a determinação da proporção entre isótopos estáveis de carbono ( $\delta 13 C$ ) (Winter et al., 1978; Winter \& Holtum, 2002). Em 1968 Bender propôs que as plantas C3 e C4 exibiam variação no $\delta 13 C$ e foi proposto que, em plantas CAM, o $\delta 13 C$ pudesse identificar a taxa de atuação das diferentes enzimas, PEPC e RubiscoC, uma vez que PEPC discrimina menos o $C^{13}$ do que a Rubisco (Whelan et al., 1973). Plantas CAM que fixam carbono quase que exclusivamente via PEPC devem ter $\delta 13 C$ parecida com plantas $C 4(\delta 13 C$ de $-10 \%$ ), enquanto plantas que fixam carbono via RubiscoC, devem ter $\delta 13 C$ mais parecidas com plantas C3 ( $\delta 13 C$ de $-27 \%$ ) (Winter \& Holtum, 2002).

Existem numerosas variações na captura de carbono para a fotossíntese dentro do grupo que chamamos de plantas CAM. Um dos tipos de plantas CAM apresenta padrão de trocas gasosas diurnas como C3 combinado com acúmulo noturno de ácido com os estômatos fechados devido à refixação do carbono respiratório (Vesta et al., 2001; Martin et al., 1988), mas Winter (1980) reportou em Kalanchoe pinnata estômatos que não fecham completamente ao longo de todo o ciclo circadiano em plantas bem hidratadas, recebendo a denominação de CAM cíclico. Sendo o malato sintetizado $\operatorname{com} \mathrm{CO}_{2}$ atmosférico ou provindo da respiração do indivíduo, sua descarboxilação disponibiliza $\mathrm{CO}_{2}$ da respiração junto com o $\mathrm{CO}_{2}$ atmosférico para o ciclo de Calvin. Existem plantas CAM 
que, quando bem hidratadas, atuam como plantas C3 e não tem acúmulo de malato no período noturno, são denominadas plantas CAM facultativo. Plantas CAM cíclico e facultativo modificam o período de assimilação de $\mathrm{CO}_{2}$ atmosférico em condições de menor disponibilidade hídrica, com abertura dos estômatos durante as fases I, II e IV. Esse padrão de abertura dos estômatos é característico de plantas CAM obrigatório, mesmo quando bem hidratadas. Quando em estresse hídrico prolongado, a maioria das espécies de CAM cíclico e as espécies CAM facultativo e obrigatório mantêm os estômatos fechados durante todo o ciclo circadiano, sem trocas gasosas com o ambiente, quando a única fonte de carbono para a fotossíntese é o $\mathrm{CO}_{2}$ liberado pelo processo de respiração do indivíduo (Bastide et al., 1993), denominado CAM “idling” (Hanscom \& Ting, 1978; Martin \& Jackson, 1986). O tipo CAM "idling", que faz com que não haja ganho de biomassa, mas também não há perda de carbono (Luttge, 1987), é utilizado para manter ativo o aparato fotossintético durante prolongado período de seca (Szarek et al., 1973), importante adaptação para ocupar ambientes xéricos. A maior eficiência de uso da água alcançada com a plasticidade nos padrões de movimento estomático e nos tipos de fotossíntese garante competitividade às plantas CAM em ambientes xéricos, resultando na ocupação de ambientes inacessíveis para outras plantas.

As plantas CAM suportam longos períodos sem aporte de água mantendo trocas gasosas com o ambiente somente durante a fase I antes de alcançar o CAM "idling". O padrão de disponibilidade hídrica define o padrão de abertura estomatal e, portanto a concentração de malato acumulado durante a noite (Szarek \& Ting, 1974). A abertura estomatal não sofre variação, em Agave deserti, depois de oito dias sem irrigação, depois decai linearmente (Bastide et al., 1993) e cessa após 44 dias (Nobel, 1976), em Opuntia ficus-indica a abertura estomatal cessa após 65 dias sem irrigação (Acevedo et al., 1983). 
Ceusters et al. (2009) conduziu um experimento com Aechmea MAYA mantida durante seis meses sem hidratação, onde após 15 dias de seca a fixação nas fases II e IV diminuíram entre 20 e $30 \%$ e a fase I não foi afetada, em 28 dias a fase IV fixa apenas $20 \%$ comparado ao controle e a fase II não tem abertura dos estômatos. Em 45 dias só ocorre trocas gasosas na fase I, correspondendo a $20 \%$ em relação ao controle, em 140 dias ocorria o CAM "idling" e em 180 dias o acumulo de malato era de $6 \%$ comparado ao controle.

Utilizando o tipo CAM “idling” as plantas suportam seis meses ou mais sem água. Tecidos fotossintetizantes funcionais após longo período de estresse conferem ao individuo a possibilidade de aproveitar eventos de disponibilidade hídrica esporádica ou escassa. Durante a chuva o potencial hídrico da raiz aumenta rapidamente, indicando que as raízes perto da superfície do solo estão aptas a fazer prontamente absorção e uso da água recém-disponível (Szarek \& Ting, 1974), mesmo as chuvas sendo irregulares dentro do ciclo anual, mas de, no mínimo, sete mm, para Agave deserti (Nobel, 1976). Em Opuntia basilaris, Szarek et al., (1973) descreve que depois de um dia de chuva intensa o valor máximo de acumulo de malato no tecido aumentou $45 \%$ e em três dias depois da chuva era $200 \%$ maior em relação ao estado de desidratação. Isso indica que mesmo capaz de fazer a fixação logo após a chuva a capacidade máxima de acumular malato só é alcançada três dias depois da chuva. Quando reidratadas as plantas voltam a realizar o tipo de CAM faziam antes assumir o tipo CAM "idling" ou obrigatório. A transição de CAM obrigatório para CAM intermediário é um processo gradual. Em Clusia minor mudando de CAM para $\mathrm{C} 3$ a tomada de $\mathrm{CO}_{2}$ ao longo de $24 \mathrm{~h}$ (fixação no escuro e fixação ao longo do dia de $\mathrm{CO}_{2}$ atmosférico) é o dobro em relação à mesma planta executando exclusivamente CAM, mas a eficiência de uso da água foi reduzida para um terço (Mattos et al., 2001). 
Para suportar longos períodos de desidratação as plantas CAM podem apresentar características morfológicas como órgãos para a coleta e o armazenamento de água. Geralmente células cilíndricas densamente organizadas com grandes vacúolos formam um tecido CAM típico. As plantas CAM epifíticas costumam ter estruturas na raiz (velame) ou nas folhas (tricomas absorventes) para a captura de água de chuvas e diretamente da atmosfera em situações de alta umidade relativa do ar. Além disso, bromélias epífitas podem ter folhas em forma de tanque onde a água obtida de chuvas é armazenada por vários dias (Lee et al., 1989). As plantas podem armazenar água dentro de tecidos especializados. Hidrênquimas ou parênquimas aquíferos são tecidos aclorofilados que podem ser periféricos, como lâminas epiteliais largas em $M$. crystallinum, camadas de células epidérmicas e subepidérmicas, como nas folhas de peperômia e bromélias (Lee et al., 1989) ou tecido central nas folhas de agaves e nos caules suculentos de diversas espécies de plantas CAM. Sob estresse hídrico, a água pode ser remobilizada dos tecidos de armazenamento para proteger tecidos fotossinteticamente ativos por muitas semanas (Schulte \& Nobel, 1989). Quando a planta perde mais que 50\% do seu conteúdo hídrico ela pode morrer. Em Peperômia magnoliaefolia o hidrênquima pode perder entre $75-85 \%$ enquanto os tecidos fotossintéticos sofrem danos com apenas $15-25 \%$ de perda de água (Schmidt \& Kaiser, 1987). O trânsito de água do hidrênquima para os tecidos fotossintetizantes já foi demonstrado em A. deserti, Ferocactus acanthodes (Tissue et al., 1991) e Opuntia ficus-indica (Goldstein et al., 1991). A presença de folhas ou caules suculentos para armazenamento de água e malato são características comuns em plantas CAM de alta exposição solar. Folhas suculentas não é condição obrigatória para a expressão do tipo CAM de fotossíntese (Coutinho, 1968), sendo que muitas plantas CAM epífitas tem folhas delgadas. 
Foram descritas 1.800 espécies de plantas CAM de alta exposição solar, que ocupam ambientes áridos e semi-áridos como agaves com folhas suculentas e cactos com folhas modificadas em espinhos e caules fotossintetizantes, e 10.000 espécies de plantas CAM epífitas, que ocupam ambientes semi-sombreados e com alta umidade relativa do ar, como orquídeas e bromélias epífitas na floresta tropical (Luttge et al., 2000). As plantas CAM são capazes de ocupar ambientes áridos onde plantas C3 não tem a aptidão de se desenvolver devido ao reduzido volume de água disponível, sendo que a fisionomia dos desertos é caracterizada por cactos, agaves e euforbiáceas (Luttge et al., 2000). Entretanto, o número de espécies CAM na floresta tropical é maior do que o número de espécies CAM típicas de ambientes áridos. Os mecanismos evolutivos que levam à especiação no ambiente de floresta tropical e as diferenças entre as espécies de epífitas, onde diferentes espécies e gêneros são anatomo-fisiologicamente muito próximos, também fazem com que a comparação de número de espécies de CAM em ambientes áridos e em florestas tropicais não traga nenhuma conclusão significativa.

Estima-se que 10\% das plantas vasculares sejam epífitas (aprox. 23.500 spp.) (Luttge, 1989), na floresta tropical 57\% das epífitas são CAM (Luttge, 2004). Na floresta tropical chuvosa extremamente úmida existem espécies de Aechmea C3 e CAM e, quando a fixação de $\mathrm{CO}_{2}$ ocorre durante o dia, as espécies $\mathrm{CAM}$ absorvem mais $\mathrm{CO}_{2}$ quando comparadas com as espécies C3. Nesse caso, o filme de água que cobre a folha impede a espécie C3 de fazer trocas gasosas durante o dia enquanto a espécie CAM pode fazer refixação do $\mathrm{CO}_{2}$ respiratório durante esses eventos (Pierce et al., 2002). Quando em estresse hídrico, a economia de água confere vantagem às espécies CAM, pela modificação do seu padrão de abertura estomatal. A flexibilidade de CAM frente à C3 é a principal 
característica que dá suporte para a radiação recente dessa via fotossintética nas florestas pluviais (Pierce et al., 2002).

Para as plantas terrestres, o maior benefício de CAM é considerado o aumento da eficiência do uso da água (Luttge, 2004). O fator que leva ao sucesso desse modelo fotossintético parece ser a economia da água capacitando o indivíduo a suportar longos períodos de seca. Um tipo de ambiente onde o estresse hídrico é uma característica são as ilhas de vegetação em afloramentos rochosos.

Nos afloramentos rochosos as plantas estão sujeitas a baixa capacidade de retenção de água e nutrientes, alta irradiância, ventos intensos e ocorrência de temperaturas noturnas congelantes (Meirelles, 1996; Medina et al., 2006). Outra característica que pode ser encontrada em diversos afloramentos rochosos é a rocha matriz em forma de domo, que provém diversas orientações de vertentes. A vegetação de afloramento rochoso de quartzo ocupa poções de substrato isoladas pela rocha matriz aflorada e nua. Esse arranjo espacial da vegetação recebe a denominação de ilhas de vegetação.

Os afloramentos rochosos graníticos são comuns nas regiões tropicais, onde constituem paisagens de notável beleza cênica e de singularidade florística. Os afloramentos rochosos mais ricos em diversidade de espécies e em endemismo, segundo Porembski (2007), estão no sudeste do Brasil, em Madagascar e no sudoeste da Austrália, ocupados por vegetação peculiar caracterizada por alterações para adaptação aos ambientes xerofíticos. Sobre a rocha aflorada algumas espécies têm a capacidade de se fixar em pequenas irregularidades levando ao acúmulo de fragmentos da rocha matriz que servem de substrato para outras espécies, que recebe o nome de ilha de vegetação. 
Meirelles (1996) denomina tais formações rupestres como "refúgios vegetacionais" ou "relíquias de vegetação". Domos monolíticos de granito, isolados floristicamente, apresentam acentuadas características de refúgio de flora xérica e elevada ocorrência de micro endemismos (Meirelles et al. 1997; Meirelles et al. 1999; Porembski \& Barthlott, 2000; Medina et al. 2006).

Uma característica particular do afloramento rochoso do Parque Estadual Monumento Natural Pedra Grande entre os demais afloramentos rochosos é a grande extensão de rocha exposta, contínua e, comparando com outros afloramentos rochosos, com grande área plana, permitindo assim a fixação de ilhas de vegetação com diversos tamanhos em diversas situações referentes á disponibilidade hídrica, como existência de calhas de drenagem que constituem ambiente preferencial para o acumulo fragmentos de rocha, que são povoados por plantas gerando uma ilha de vegetação.

Outro ponto particular do Afloramento Rochoso Pedra Grande é a presença de um volume considerável de solo que se encontra em maior altitude do que as ilhas de vegetação, no cume da montanha, o que faz que, tanto a água e principalmente o substrato sejam carreados ao longo da orientação da rocha e assim alcançam ilhas de vegetação que estão nessa calha de drenagem criando um aporte de matéria que consiste em grandes fragmentos de rocha matriz e material particulado como areia e argilas. Tais materiais unem-se ás ilhas de vegetação permitindo assim, em uma primeira análise, um aporte de material mineral que deve ser incorporado à massa de protosolo da ilha de vegetação, ou ser represado por plantas pioneiras que até então estavam fixadas unicamente na rocha, onde esse acúmulo de substrato pode levar á formação de uma nova ilha de vegetação. $\mathrm{O}$ aporte de matéria mineral permite inferir que a dinâmica no 
volume e, portanto no tamanho e diversidade das ilhas de vegetação sejam variáveis ao longo do tempo.

Segundo Meirelles (1996), no domo de esfoliação da Pedra Grande foram encontradas 105 espécies de plantas vasculares e briófitas, considerando-se o afloramento rochoso e as zonas limítrofes, o que incluiu as comunidades vegetais rupestres organizadas em unidades insulares típicas ("ilhas de vegetação") e aquelas ocorrendo em fendas com substrato profundo ou diretamente sobre a rocha, bem como elementos dos campos de matacões adjacentes. Segundo o mesmo autor, a flora exclusiva das unidades insulares era constituída de 58 espécies (55\% do total), entre as quais predominavam as monocotiledôneas. As formas de vida hemicriptofíticas e geofíticas foram as mais importantes na composição da cobertura vegetal destas unidades insulares, caracterizando uma formação de fisionomia campestre. Variações sazonais nítidas na cobertura vegetal se apresentaram associadas à alta proporção de geófitas e terófitas, sendo que a máxima cobertura de partes clorofiladas se deu entre dezembro e janeiro, coincidindo com o aumento da pluviosidade (Meirelles, 1996). Os maiores valores de índice de importância no estudo realizado por Meirelles (1996) dentre as 58 espécies encontradas no conjunto de ilhas de vegetação presentes na Pedra Grande, em ordem decrescente, são: Hippeastrum damazianum, Dyckia tuberosa, Axonopus barbigerus, Epidendrum ellipticum, Tillandsia araujei, Tibouchina mosenii, Anturio sp. novae, Alstroemeria nemorosa, Cuphea thymoides, Clusia criuva, Panicum cyanecsens, Stevia hypericifolia, Tibouchina ursina, Rypsalis spinescens, Coccocypselum condalia, Peperomia reflexa.

Entre as bromeliáceas encontramos no afloramento rochoso Pedra Grande duas espécies terrestres (Pitcairnia flammea e Dyckia tuberosa), três espécies atmosféricas 
(Tilandsia araujei, T. streptocarpa e T. stricta) e duas espécies de bromélia-tanque (Aechmea distichanta e Vriesea sp.).

Na época seca a cobertura das ilhas de vegetação é dominada por Dyckia tuberosa (Vellozo) Beer, presente na maioria das ilhas de vegetação. Dyckia tuberosa tende a ser ausente em ilhas de vegetação com área maior que 15 metros ao longo do maior eixo e/ou ilhas com fanerógamas, fanerógamas essas que geralmente tem porte reduzido determinado pelo reduzido volume do substrato. O domínio de Dyckia tuberosa, identificada como segunda espécie em área de cobertura (Meirelles, 1996), serve como indicador da presença nessa espécie de características fisiológicas que permitam ocupar aquele ambiente seletivo com sucesso, lidando com a seca edáfica por pouco volume de substrato.

Dyckia tuberosa é o principal componente insular entre as bromeliáceas e um dos mais importantes em toda a comunidade vegetal rupícola, desempenham papel semelhante no pioneirismo, na agremiação e manutenção da integridade do protosolo com raízes volumosas que se fixam na rocha através de pequenas radículas e raízes secundárias (Meirelles, 1996). D. tuberosa é endêmica do Brasil ocorrendo no Cerrado e na Mata Atlântica em Minas Gerais, São Paulo, Paraná e Santa Catarina (Crayn et al., 2004). Dyckias são todas CAM obrigatório e a desenvolveram em uma linhagem independente do aparecimento de CAM em relação a outros grupos de bromélias (Crayn et al., 2004). Dyckia, um gênero especializado, obteve a mais alta taxa de tomada de $\mathrm{CO}_{2}$ e acumulo de ácido do que as outras espécies estudadas (Williams, 1970). Diferentes espécies usam diferentes fontes de carboidratos (Ceusters et al., 2009). Dyckia usa sacarose com principal substrato de fixação noturna de carbono, enquanto amido tem menor importância (Ceusters et al., 2009). 
O presente estudo busca elucidar como as variáveis climáticas e as características de cada ilha de vegetação afetam a dinâmica circadiana do ciclo do malato em uma planta CAM obrigatória. A temperatura, o volume de PAR e, principalmente, a disponibilidade hídrica são variáveis que afetam a fisiologia das plantas CAM, mas como os extremos dessas variáveis que ocorrem no afloramento rochoso influenciam uma espécie nativa desse ambiente é uma pergunta que não havia sido investigada. As características particulares de cada ilha de vegetação, como a área, a inclinação, e a posição no domo do afloramento rochoso podem levar a variações da disponibilidade hídrica, da temperatura e da exposição solar, portanto, á variações fisiológicas de CAM. As variações do metabolismo ácido crassuláceo foram mensuradas a partir da variação da concentração de malato no mesofilo de Dyckia tuberosa.

Sendo Dyckia tuberosa uma espécie adaptada a tais extremos climáticos, o esperado é que a disponibilidade hídrica seja o principal responsável pela variação de concentração de malato aferida. Para deixar clara a relação entre a disponibilidade hídrica e a concentração de malato no mesofilo no ambiente natural foram realizados experimentos em um ambiente semi-controlado. 


\section{MATERIAIS E MÉTODOS}

1- Caracterização do ambiente

O estudo foi realizado no afloramento rochoso do Parque Estadual Monumento Natural Pedra Grande, que faz parte do mosaico de áreas de conservação denominado Parque Estadual da Serra do Itapetinga, criado em março de 2010. De coordenadas geográficas centrais aproximadas de $23^{\circ} 08^{\prime} \mathrm{S}$ e $46^{\circ} 35^{\prime} \mathrm{O}$ e altitude oscilando entre 900 e 1460 metros, abrange porção da Serra do Itapetinga, incluída no sistema de dobramentos sudeste do embasamento cristalino do Planalto Atlântico, fazendo parte da Serra da Mantiqueira (Almeida et al. 1981). O sistema foi consolidado no final do Proterozóico e o Cambro-Ordoviciano (Carneiro \& Souza, 2003). Na região afloram corpos graníticos formados durante a consolidação da Plataforma Sul-Americana, entre 600 e 400 milhões de anos (Carneiro \& Souza, 2003), comportando uma suíte de rochas graníticas de granulação irregular e grossa, compostas de quartzo, microclína, plagioclásio, biotita e hornblenda (Cavalcante et al., 1998). Dentre estes afloramentos, o Maciço Granítico Atibaia, conhecido como Pedra Grande, destaca-se na paisagem com seu domo de esfoliação esferoidal.

O clima da região é do tipo Cfb segundo a classificação de Köeppen (temperado, apresentado temperaturas relativamente elevadas durante todo o ano). A média anual de temperatura é de $19.7^{\circ} \mathrm{C}$, variando entre $15.9^{\circ} \mathrm{C}$, em julho, até $22.3^{\circ} \mathrm{C}$ em fevereiro. Os meses com maiores índices pluviométricos são dezembro e janeiro, com totais de $204,6 \mathrm{~mm}$ e $260,8 \mathrm{~mm}$, respectivamente. O período de seca ocorre de abril a setembro. 
2.1- Material em condições semi-controladas (casa de vegetação)

Durante as incursões exploratórias no afloramento rochoso Pedra Grande durante o ano de 2008 foram coletadas sementes de diversas espécies de vegetação xérica nas ilhas de vegetação. Uma das espécies que teve sementes coletadas foi a bromélia Dyckia tuberosa.

A semente de $D$. tuberosa é pequena, anemocórica, liberada pelo fruto maduro na ponta do pedúnculo floral de comprimento entre 20 e $30 \mathrm{~cm}$. Os frutos foram coletados maduros e em agosto de 2008 sementes foram germinadas em placas de petri sobre papel de filtro esterilizado e saturado de água deionizada. Em seguida as plântulas foram levadas para germinadeiras de isopor com substrato comercial esterilizado. A taxa de germinação foi alta. Em dezembro de 2008 e janeiro de 2009 cerca de 400 indivíduos foram transplantados para vasos pequenos. Em janeiro de 2010 as plantas jovens foram transplantadas para vasos médios. Os vasos eram do mesmo tamanho e alguns receberam um indivíduo e outros receberam três indivíduos de $D$. tuberosa.

Os vasos foram mantidos dentro da casa de vegetação, com irrigação diária. Além da irrigação diária os vasos eram regados uma vez por semana com água e nutrientes (NPK 10-10-10 + micronutrientes na concentração de um grama por litro). A fim de preparar as plantas para o experimento, onde receberiam regas semanais e não diárias, os vasos foram retiradas da irrigação diária e durante os meses de julho e agosto de 2011 os vasos foram regados uma vez por semana com nutrientes $(0,5 \mathrm{~g} / \mathrm{l})$ e durante o mês de setembro os vasos foram regados uma vez por semana com água sem os nutrientes. 
Foram selecionados 138 vasos com plantas que apresentavam folhas com mais de 15 centímetros. Destes, 78 vasos continham apenas uma roseta (vasos com uma planta) e 60 vasos tinham três rosetas (vasos com três plantas). Os vasos foram separados em dois grupos nominados "bloco 1" (tabela 1), com uma roseta por vaso, e "bloco 2" (tabela 1), com três rosetas por vaso. Todos os vasos tinham o mesmo volume de substrato e recebiam o mesmo volume de água durante a rega. Desde 2009, os vasos foram mantidos sempre na mesma orientação em relação ao sol.

Para obter plantas em diferentes estágios de desidratação as plantas deixaram de se regadas ao longo de 83 dias. Para isto foram selecionados grupos composto de seis vasos, três vasos para a coleta matinal e três vasos para a coleta vespertina. O "bloco 1", com 78 vasos (treze grupos) e o "bloco 2", com 60 vasos (dez grupos). A cada semana um grupo de cada bloco deixou de ser regado e os outros continuaram a receber água uma vez por semana. O último grupo foi regado de manhã e as coletas ocorreram no final desse dia e no começo da manhã seguinte. Foram coletadas três folhas de cada vaso em cada grupo para que fosse feita a titulação da acidez do mesofilo da folha de $D$. tuberosa no final da tarde (M1) e no começo da manhã (M2) (tabela 1). De cada vaso eram retiradas três folhas adultas e não senescentes que tinham o limbo foliar voltado para norte. Sendo três vasos de cada grupo, foram processadas nove folhas de cada grupo.

O delineamento apresentado acima para o ensaio de resposta à seca em $D$. tuberosa foi preferido em detrimento de outros, como por exemplo, cessar a rega de todos os grupos e fazer uma coleta semanal, pois existem muitos atributos ambientais que interferem na capacidade de acumular malato em plantas CAM. Foi considerado que o total de PAR ao longo do dia, sendo que a concentração de malato acumulado durante a noite é influenciado pelo volume de PAR ao longo do dia (Acevedo et al., 1983). Para evitar 
a variação das características ambientais que podem influenciar na capacidade de acumular malato ao longo da noite todas as coletas foram realizadas no mesmo dia. Outros fatores ambientais que podem variar e influenciam a capacidade de acumular malato são a umidade relativa do ar, temperatura e duração do período luminoso. Esses fatores não foram controlados e seus possíveis efeitos serão convenientemente discutidos.

As folhas foram cortadas em segmentos de aproximadamente três centímetros. Os segmentos da base e da ponta da folha foram descartados. Segmentos foram separados aleatoriamente até somar dois gramas de peso e esse material teve sua acidez titulada.

Tabela 1 - Descrições, siglas e unidades das variáveis mensuradas durante as campanhas amostrais na casa de vegetação.

\begin{tabular}{lll}
\hline sigla & descrição da variável & unidade \\
ADAM & variação líquida da acidez titulável duranta a noite & $\mu \mathrm{mol} / \mathrm{l}$ \\
M1 & acidez titulável do mesofilo no final da tarde & $\mu \mathrm{mol} / \mathrm{l}$ \\
M2 & acidez titulável do mesofilo no começo da manhã & $\mu \mathrm{mol} / \mathrm{l}$ \\
DSR & número de dias sem rega & dias \\
Bloc & grupos 1(1 planta no vaso)e 2(2) & \\
\hline
\end{tabular}

\section{2- Coletas no ambiente natural}

Para a realização desse trabalho foi necessário um mapeamento preliminar das ilhas de vegetação do afloramento rochoso do Monumento Natural Pedra Grande. Entre agosto de 2007 e setembro de 2009 ocorreram incursões quinzenais de 6 horas resultaram em um mapa detalhado da disposição das ilhas de vegetação sobre o afloramento rochoso. Cada ilha de vegetação foi georeferenciada via GPS (Global Position System) e recebeu uma placa de alumínio de $2 \times 4 \mathrm{~cm}$ com um número de identificação fixada na rocha 
matriz com massa plástica. Uma foto aérea foi usada como base para a localização dos pontos in situ e através dos pontos de GPS. Foram descartadas as ilhas de vegetação com menos de três espécies de plantas vasculares e as ilhas de vegetação que estavam em fendas na rocha matriz. Esse procedimento identificou 1600 ilhas de vegetação.

Entre as 1600 ilhas de vegetação, foram identificadas 196 ilhas de vegetação com comprimento menor que oito metros e maior que 0,3 metros ao longo do seu maior eixo, com inclinação menor que $35^{\circ}$. Nessas 196 ilhas de vegetação foi identificada a presença ou não de $D$. tuberosa e o número de rosetas. Entre as 196 haviam 41 ilhas de vegetação com mais de 75 rosetas de $D$. tuberosa. Tais ilhas de vegetação foram utilizadas no ensaio sobre amplitude circadiana do acúmulo de malato (ADAM), acidez titulável no mesofilo no começo da manhã (M2) e acidez titulável do mesofilo no final da tarde (M1) (tabela 2).

Em cada ilha foram executadas 18 coletas. Nove coletas ocorreram na hora do ocaso e outras nove coletas ocorreram na alvorada do dia seguinte. Em cada uma das 41 ilhas foram coletadas três folhas de uma roseta intacta, que não sofreu coleta anterior e que não apresentava folhas secas na base. As coletas ocorriam sempre depois de um dia de sol intenso, para evitar que um baixo valor de PAR acumulado ao longo do dia anterior levasse a uma baixa concentração de malato acumulado durante a noite.

Para caracterizar as variações ambientais ao longo da amostragem foram utilizados dados cedidos pelo IAC (Instituto Agronômico de Campinas) para o município de Atibaia São Paulo. Foram utilizados os dados de precipitação, umidade máxima e mínima do ar, temperaturas máximas e mínimas do ar e RGT (Radiação Global Total) (tabela 2). Para entender como essas variáveis afetam, em diferentes escalas de tempo, a capacidade de acumular malato em $D$. tuberosa foram utilizados os valores das variáveis no dia da coleta, 
a média dos valores de cada variável nos três dias e nos sete dias que antecederam a coleta.

Para caracterizar as variações entre as diferentes ilhas de vegetação foram selecionados atributos particulares de cada uma como a inclinação e a área que a ilha de vegetação ocupa na rocha matriz e a posição no afloramento rochoso Pedra Grande ocupada pela ilha de vegetação diferenciando os eixo norte-sul e leste-oeste (tabela 2). A área da ilha de vegetação foi obtida através de um croqui feito para cada uma das 41 ilhas de vegetação buscando relacionar diferentes partes da ilha com figuras geométricas, medindo in loco os segmentos de cada parte das figuras geométricas para determinar a área de cada figura e somando as áreas de todas as figuras que formaram a ilha de vegetação tivemos um valor aproximado da área de cada ilha de vegetação. Entre as ilhas de vegetação ocorreram formatos irregulares. Mas a maioria das ilhas de vegetação é elíptica, com o maior eixo no mesmo plano da inclinação da rocha matriz.

Para determinar a inclinação da rocha matriz que sustenta a ilha de vegetação foi utilizado um clinômetro para medir a inclinação de uma linha esticada sobre a ilha de vegetação ao longo do eixo de maior inclinação da rocha matriz, suportada nas pontas por dois suportes da mesma altura. A linha não tocava a vegetação da ilha. A posição ao longo do eixo oeste-leste e norte-sul foram obtidas através dos dados obtidos com GPS in situ. 
Tabela 2. Descrições, siglas e unidades das variáveis mensuradas durante as campanhas amostrais na Pedra Grande, município de Atibaia (SP).

\begin{tabular}{lll}
\hline sigla & descrição da variável & unidade \\
ADAM & variação líquida da acidez titulável duranta a noite & $\mu \mathrm{mol} / \mathrm{l}$ \\
M1 & acidez titulável do mesofilo no final da tarde & $\mu \mathrm{mol} / \mathrm{I}$ \\
$\mathrm{M} 2$ & acidez titulável do mesofilo no começo da manhã & $\mu \mathrm{mol} / \mathrm{l}$ \\
Area & área da ilha de vegetação & $\mathrm{m}^{2}$ \\
Incl & inclinação da rocha matriz & $\mathrm{graus}$ \\
$\mathrm{X}$ & coordenadas oeste-leste & \\
Y & coordenadas norte-sul & \\
Prec0 & precipitação no dia da coleta & $\mathrm{mm}$ \\
Prec3 & média da precipitação nos três dias que precedem a coleta & $\mathrm{mm}$ \\
Prec7 & média da precipitação nos sete dias que precedem a coleta & $\mathrm{mm}$ \\
URmax0 & Umidade Relativa máxima no dia da coleta & $\%$ \\
URmax3 & média da Umidade Relativa máxima nos três dias que precedem a coleta & $\%$ \\
URmax7 & média da Umidade Relativa máxima nos sete dias que precedem a coleta & $\%$ \\
URmin0 & Umidade Relativa mínima no dia da coleta & $\%$ \\
URmin3 & média da Umidade Relativa mínima nos três dias que precedem a coleta & $\%$ \\
URmin7 & média da Umidade Relativa mínima nos sete dias que precedem a coleta & $\%$ \\
Tmax0 & Temperatura máxima no dia da coleta & ${ }^{\circ}$ \\
Tmax3 & média da Temperatura máximo nos três dias que precedem a coleta & ${ }^{\circ} \mathrm{C}$ \\
Tmax7 & média da Temperatura máximo nos sete dias que precedem a coleta & ${ }^{\circ} \mathrm{C}$ \\
Tmin0 & Temperatura mínima no dia da coleta & ${ }^{\circ} \mathrm{C}$ \\
Tmin3 & média da Temperatura mínima nos três dias que precedem a coleta & ${ }^{\circ} \mathrm{C}$ \\
Tmin7 & média da Temperatura mínima nos sete dias que precedem a coleta & ${ }^{\circ} \mathrm{C}$ \\
RGT0 & Radiação global total no dia da coleta & ${ }^{\circ} \mathrm{C}$ \\
RGT3 & média da Radiação global total nos três dias que precedem a coleta & $\mathrm{MJ} / \mathrm{m}^{2}$ \\
RGT7 & média da Radiação global total nos sete dias que precedem a coleta & $\mathrm{MJ} / \mathrm{m}^{2}$ \\
\hline & & $\mathrm{MJ} / \mathrm{m}^{2}$ \\
\hline
\end{tabular}

3- Titulação da acidez do mesofilo

Para fazer a análise da acidez titulável de cada roseta foram coletadas três folhas em cada coleta, cortadas com estilete a uma distância não maior do que quatro centímetros da inserção da folha na roseta. As três folhas foram armazenadas em saco de plástico identificado pelo número do vaso e do bloco (coletas na casa de vegetação) ou pelo número da ilha de vegetação (coletas no afloramento rochoso Pedra Grande). Foi 
utilizado um plástico impermeável e grosso a ponto de não ser perfurado pelas projeções laterais da folha em forma de espinho.

As folhas foram acomodadas a $0^{\circ} \mathrm{C}$ por um período máximo de 60 minutos e depois conservadas em $-20^{\circ} \mathrm{C}$ por um período máximo de 72 horas antes de terem a acidez do mesofilo titulada. As folhas, que tinham dimensões de 12 a $25 \mathrm{~cm}$ de comprimento e entre 0,7 e 1,7 cm de largura na base, foram cortadas em segmentos de dois a três centímetros e pesadas. Entre esses segmentos foram retirados de forma aleatória (sorteando em um recipiente) segmentos necessários para alcançar dois gramas, que foi fervido em água deionizada, triturado por 120 segundos em liquidificador comercial e filtrado a vácuo em papel filtro. O líquido resultante da filtração teve sua acidez titulada adicionando $\mathrm{NaOH}(0,01 \mathrm{~N})$ até $\mathrm{pH} 8,0$ conforme descrito por Cockburn et al. (1985). A fim de determinar a concentração da acidez titulável foi aceito, para fins analíticos, que o material no mesofilo responsável pela acidez titulável era o ácido málico $\left(\mathrm{C}_{4} \mathrm{H}_{6} \mathrm{O}_{5}\right)$ e sua concentração foi inferida a partir da concentração de $\mathrm{NaOH}$. O volume de $\mathrm{NaOH}(0,01 \mathrm{~N})$ utilizado na titulação foi inserido na fórmula:

$$
C_{1} \times V_{1} \times 1=C_{2} \times V_{2} \times 2
$$

Onde $C_{1}$ é a concentração de $\mathrm{NaOH}, V_{1}$ é o volume de $\mathrm{NaOH}$ utilizado na titulação, 1 é o número de grupos de base em $\mathrm{NaOH}, C_{2}$ é a concentração dos ácidos tituláveis na extração do mesofilo de $D$. tuberosa e $V_{2}$ é o volume do extrato, e 2 é o número de grupos de ácidos no malato.

As coletas de amostras de $D$. tuberosa no afloramento rochoso seguiram o mesmo protocolo que as coletas na casa de vegetação sendo que de cada ilha de vegetação foi 
retirado três folhas de Dyckia tuberosa identificadas, isoladas e congeladas, armazenadas e tituladas.

4- Técnicas de análises estatísticas

Os dados correspondentes aos tratamentos foram comparados levando em conta os valores obtidos em cada intervalo. A maior parte dos dados permitiu o emprego de técnicas paramétricas tendo sido aplicadas comparações entre médias segundo modelos lineares. Para análises envolvendo área foi utilizada a transformação logarítmica dos dados. As relações entre variáveis do ambiente físico na região da Pedra Grande obtidas a partir das medições da estação climática e os valores de acidez foliar (ADAM, M1 e M2) foram estabelecidas a partir de análises de correlação empregando-se o coef. de correlação de postos de Spearman. As representações gráficas das variações nas medidas foram feitas através de diagramas de box-plot com valores de desvio- padrão, mediana e amplitude. As análises estatísticas e gráficos descritivos dos dados foram feitas através do software Minitab (Minitab, 2003). 


\section{RESULTADOS}

A disponibilidade hídrica pode ter sido a causa das diferenças na concentração de malato inferida pela acidez titulável do mesofilo no final da tarde (M1) e no começo da manhã (M2). A variação de M2 (figura 3) ao longo dos 84 dias sem hidratação foi maior do que a variação de M1 (figura 2). Ao longo da seca a no começo da manhã (M2) diminuiu e no final da tarde (M1) aumentou. O sentido inverso das tendências leva a uma diminuição no valor de ADAM (figura 1) em situações de estresse hídrico através dos dois mecanismos, a diminuição de M2 e o aumento de M1. Embora grande parte da variação no ADAM advir da diminuição de $M 2$, o aumento do $M 1$ não é desprezível.

No ambiente da casa de vegetação o ADAM varia entre $274,7 \mu \mathrm{mol} / \mathrm{g}$ e $41,6 \mu \mathrm{mol} / \mathrm{g}$, com amplitude de $233,1 \mu \mathrm{mol} / \mathrm{g}$. O valor de $\mathrm{M} 2$ varia entre 312,8 e 87,1 , com amplitude de

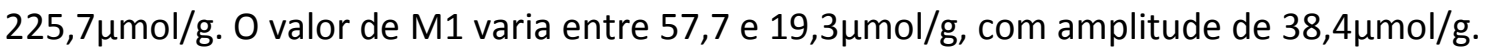
Quando bem hidratada o valor de M1 representa cerca de $10 \%$ do valor de $\mathrm{M} 2$, mas com 85 dias de privação de água M1 representa $50 \%$ do valor de M2. Se M1 mantivesse sua concentração durante a desidratação o ADAM no 84ำ dia de desidratação seria o dobro.

A acidez titulável no início da manhã (M2) alcançou um patamar após 60 dias sem rega (figura 3), quando seu valor não diminuiu mais, mantendo-se estável até o final do período sem rega, mas M1 não alcançou um patamar depois de 85 dias sem rega (figura 2), apresentando concentrações cada vez maiores com o aumento do período de estresse hídrico. Ao final do experimento as plantas foram reidratadas e todas voltaram a apresentar a aparência inicial.

A concentração de malato inferida pela acidez titulável no início da manhã (M2) variou de forma muito parecida nos dois grupos, apresentando logo no começo do período 
sem água a tendência a diminuir, embora no bloco 2 o patamar de valor mínimo é alcançado no 30 dia de estresse hídrico enquanto no bloco 1 o mesmo patamar é alcançado em 60 dias. Os patamares mínimos de M2, embora diferenciem temporalmente em cada bloco, estão entre 90 e $100 \mu \mathrm{mol} / \mathrm{g}$ de acidez titulável. A variação do ADAM seguiu a tendência apresentada por M2 (figura 1).

Para a acidez titulável no final da tarde (M1), desde o início do período sem rega o "bloco 2" demonstra uma tendência de ter uma concentração de malato mais alta quando sobre estresse hídrico, enquanto o "bloco 1" apresentou uma inversão de tendência, diminuindo até o 21으 dia sem rega e depois apresentou a tendência de subir ao longo da desidratação. Nos dois blocos a tendência ao longo da desidratação é o aumento do (M1) (figura 2).

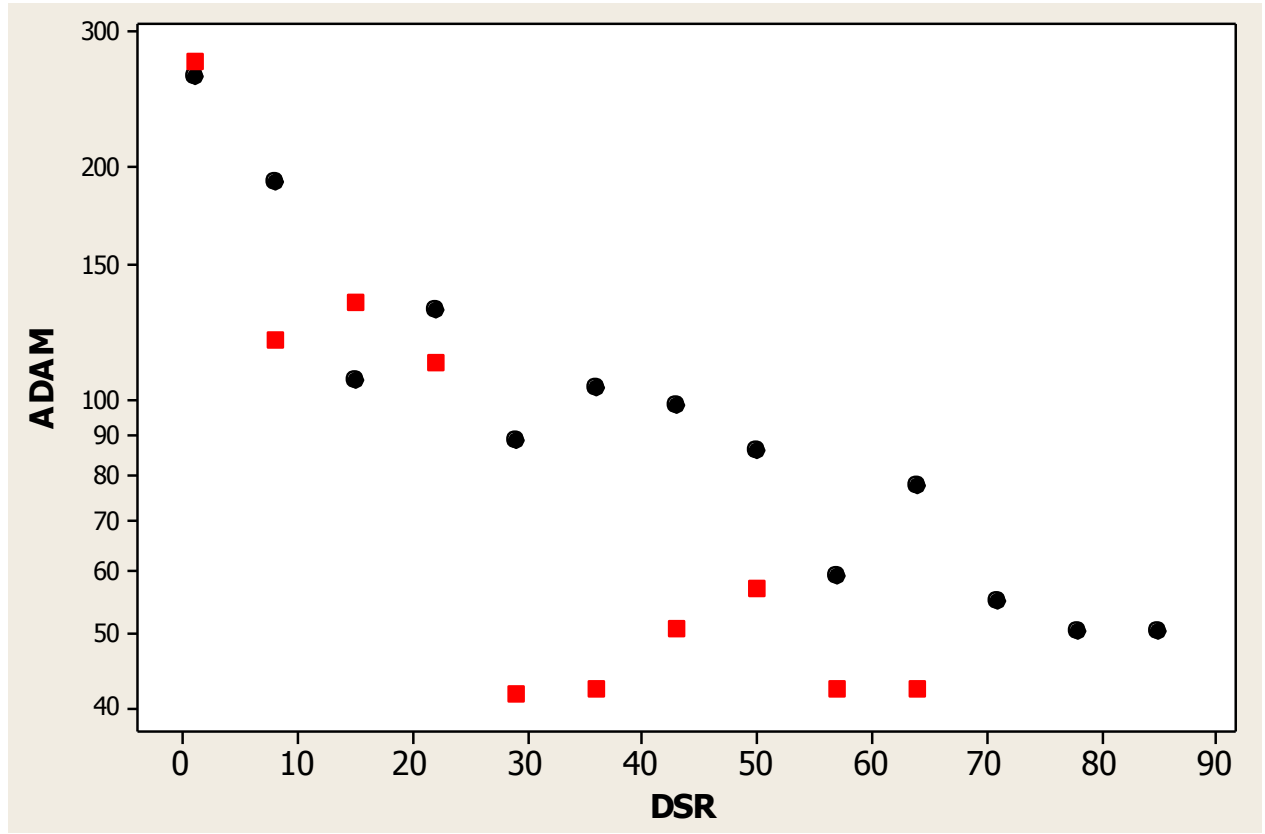

Figura 1: Relação de ADAM (amplitude diária de acúmulo de malato), em $\mu \mathrm{mol} / \mathrm{l}$, com DSR (dias sem rega), em dias. O ADAM representa a concentração líquida durante uma noite da acidez titulável no mesofilo da folha. O DSR representa o número de dias que $D$. tuberosa ficou sem receber água. As coletas ocorreram a cada sete dias. Os pontos redondos representam vasos com apenas uma roseta (bloco1) e os pontos vermelhos de vasos com três rosetas (bloco2). 


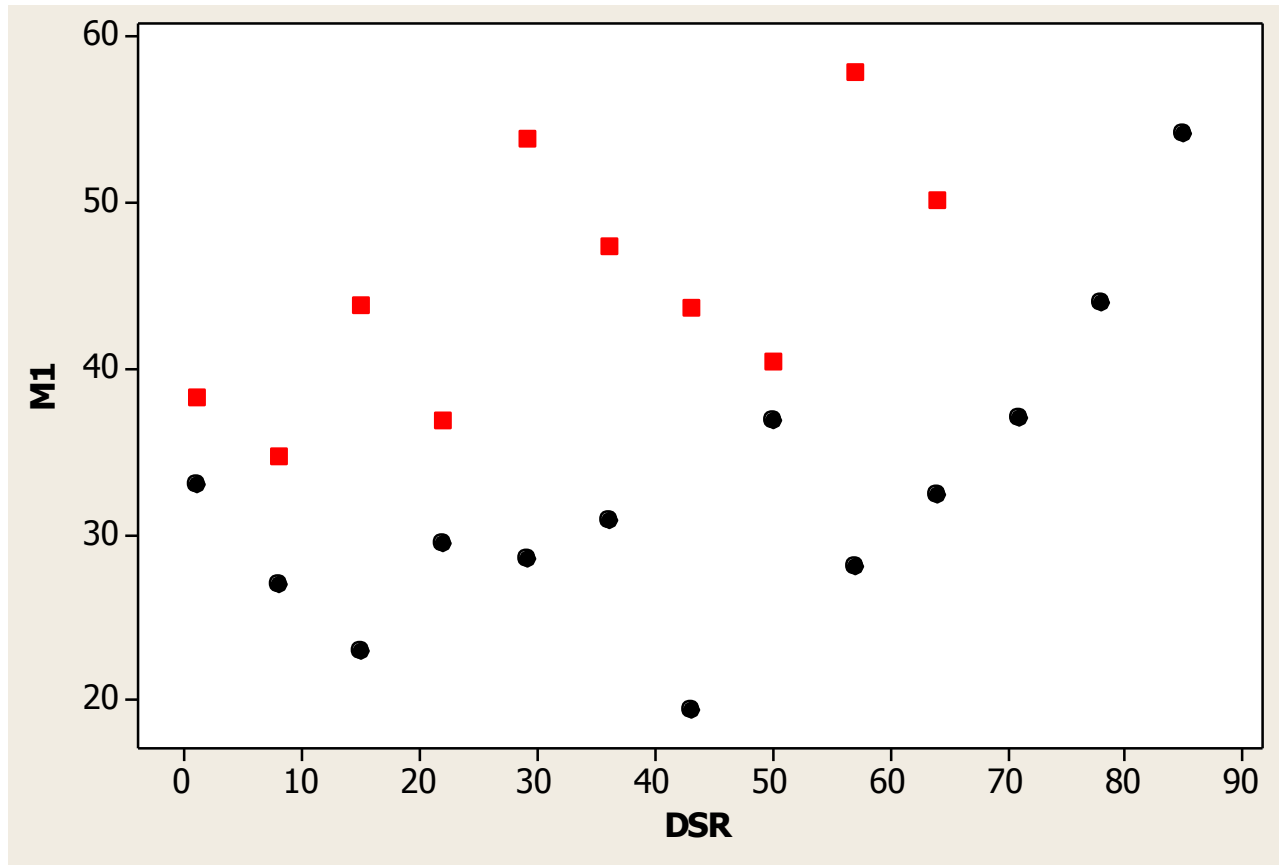

Figura 2: Relação de M1 (concentração de acidez titulável no mesofilo da folha no final da tarde), em $\mu \mathrm{mol} / \mathrm{l}$, com DSR (dias sem rega), em dias. O DSR representa o número de dias que $D$. tuberosa ficou sem receber água. As coletas ocorreram a cada sete dias. Os pontos redondos representam vasos com apenas uma roseta (bloco1) e os pontos quadrados representam vasos com três rosetas (bloco2).

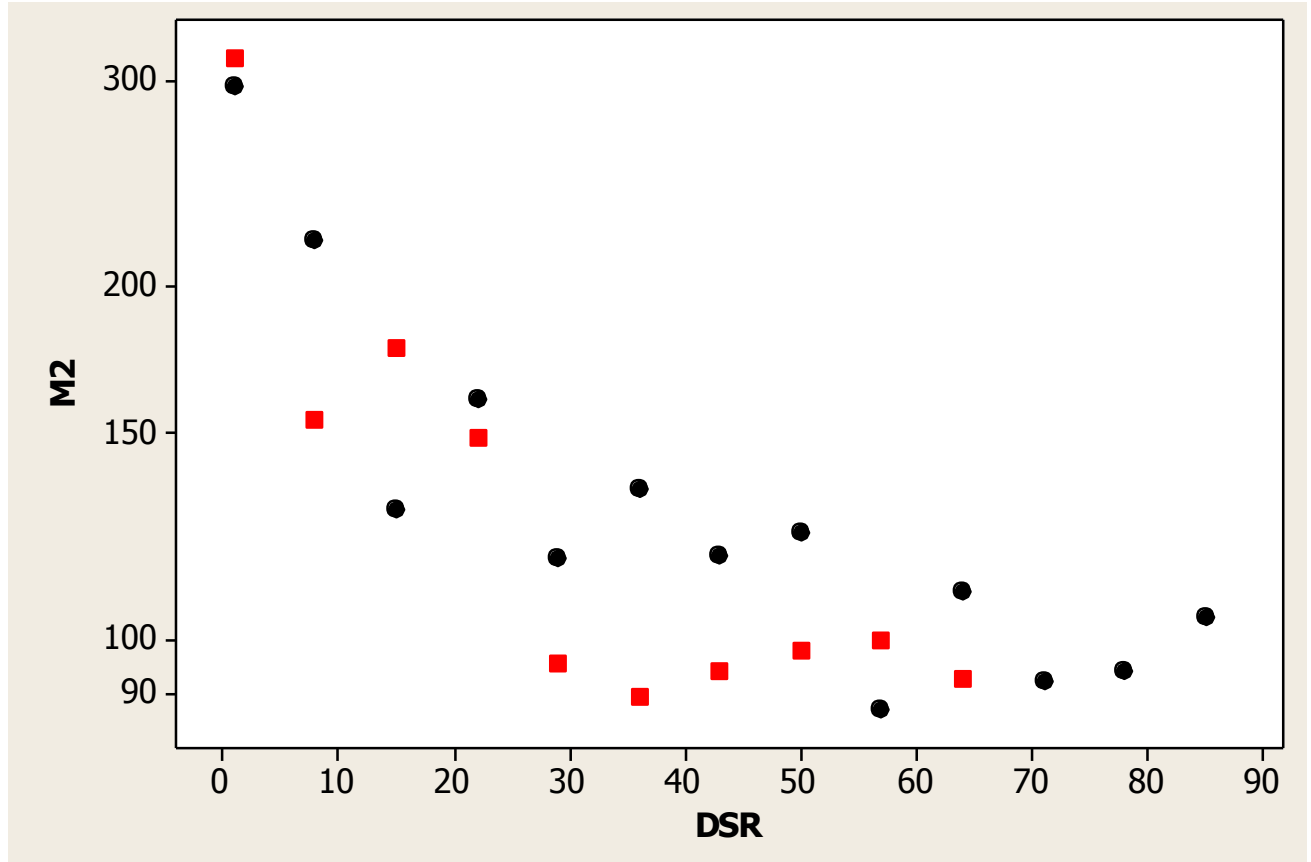

Figura 3: Relação de M2 (concentração de acidez titulável no mesofilo da folha no começo da manhã), em $\mu \mathrm{mol} / \mathrm{I}$, com DSR (dias sem rega), em dias. O DSR representa o número de dias que $D$. tuberosa ficou sem receber água. As coletas ocorreram a cada sete dias. Os pontos redondos representam vasos com apenas uma rosetas (bloco1) e os pontos quadrados representam vasos com três rosetas (bloco2). 
No afloramento rochoso do Parque Estadual Monumento Natural Pedra Grande o ADAM de $D$. tuberosa apresentou variações associadas com condições distintas de provisão hídrica. As variações foram coerentes com o padrão encontrado no ADAM de $D$. tuberosa na casa de vegetação.

De acordo com a análise de modelo linear (GLM-ANOVA) aplicada aos valores de M1, os efeitos relativos das variáveis ambientais nos sete dias que precediam a coleta foram: precipitação, 0\% (tabela 3); umidade relativa máxima, 11,28\% (tabela 4); umidade relativa do ar mínima, 3,96\% (tabela 4); temperatura máxima, 4,09\% (tabela 5); temperatura mínima, 5,73\% (tabela 5) e a RGT correspondeu a 2,72\% (tabela 6).

Os valores obtidos com a correlação de Spearman indicaram que altos volumes de precipitação e de umidade relativa do ar máxima reduzem a concentração de malato inferida pela acidez no mesofilo no final da tarde, sendo o efeito da umidade relativa do ar máxima maior que o efeito da pluviosidade, enquanto altos valores de temperatura do ar mínima e RGT levam a uma baixa concentração de $M 1$, sendo que as duas variáveis influenciam praticamente com a mesma intensidade (tabela 8).

De acordo com a análise de modelo linear (GLM-ANOVA) aplicada aos valores de M2, os efeitos relativos das variáveis ambientais nos sete dias que precediam a coleta foram: precipitação, 5,22\%; umidade relativa máxima, 20,2\%; umidade relativa do ar mínima, 5,4\%; temperatura máxima, 0\%; temperatura mínima, 2,95\% e a RGT correspondeu a $2,39 \%$.

Para a matriz de Spearman, no mesmo período, altos valores de umidade relativa do ar máxima e RGT levam a uma baixa concentração de malato no começo da manhã, sendo o efeito da umidade relativa do ar máxima maior que o efeito da RGT, enquanto 
altos valores de temperatura do ar mínima levam a alta concentração de malato no começo da manhã.

De acordo com a análise de modelo linear (GLM-ANOVA) aplicada aos valores de M1, os efeitos relativos das variáveis ambientais nos três dias que precediam a coleta foram: precipitação, 0\%; umidade relativa máxima, 7,53\%; umidade relativa do ar mínima, 13,6\%; temperatura máxima, 13,96\%; temperatura mínima, 7,98\% e a RGT correspondeu a $3,14 \%$.

Para a matriz de Spearman, no mesmo período, altos volumes de precipitação e a umidade relativa do ar máxima levam a uma baixa concentração de malato no mesofilo no final da tarde, sendo o efeito da umidade relativa do ar máxima maior que o efeito da pluviosidade, enquanto altos valores de temperatura do ar máxima e mínima levam a uma alta concentração de malato no final da tarde. A influência da temperatura máxima é maior que a influência da temperatura mínima.

De acordo com a análise de modelo linear (GLM-ANOVA) aplicada aos valores de $M 2$, os efeitos relativos das variáveis ambientais nos três dias que precediam a coleta foram: precipitação, 1,81\%; umidade relativa máxima, 19,06\%; umidade relativa do ar mínima, 4,1\%; temperatura máxima, 2,71\%; temperatura mínima, 0,31\% e a RGT correspondeu a $24,44 \%$.

Para a matriz de Spearman, no mesmo período, altos valores de pluviosidade, umidade relativa do ar máxima e mínima levam a uma alta concentração de malato no começo da manhã, sendo, em ordem decrescente de influência, a umidade relativa do ar mínima, umidade relativa do ar máxima e pluviosidade, enquanto altos valores de 
temperatura do ar máxima e RGT levam a baixa concentração de malato no começo da manhã. O efeito da RGT é maior que o efeito da temperatura do ar máxima.

De acordo com a análise de modelo linear (GLM-ANOVA) aplicada aos valores de M1, os efeitos relativos das variáveis ambientais no dia que precediam a coleta foram: precipitação, 2,58\%; umidade relativa máxima, 9,71\%; umidade relativa do ar mínima, 10,09\%; temperatura máxima, 0,75\%; temperatura mínima, 4,2\% e a RGT correspondeu a $1,57 \%$.

Para a matriz de Spearman, no mesmo período, altos volumes de precipitação e a umidade relativa do ar máxima levam a uma baixa concentração de malato no mesofilo no final da tarde, sendo o efeito da umidade relativa do ar máxima maior que o efeito da pluviosidade, enquanto alta temperatura do ar mínima leva a uma alta concentração de malato no final da tarde.

De acordo com a análise de modelo linear (GLM-ANOVA) aplicada aos valores de M1, os efeitos relativos das variáveis ambientais no dia que precediam a coleta foram: precipitação, 1,09\%; umidade relativa máxima, 3,16 \%; umidade relativa do ar mínima, 14,64\%; temperatura máxima, 10,38 \%; temperatura mínima, 0,83\% e a RGT correspondeu a $8,21 \%$.

Para a matriz de Spearman, no mesmo período, altos valores de pluviosidade, umidade relativa do ar máxima e mínima levam a uma alta concentração de malato no começo da manhã, sendo, em ordem decrescente de influência, a umidade relativa do ar mínima, pluviosidade e umidade relativa do ar máxima, enquanto altos valores de temperatura do ar máxima e mínima e RGT levam a baixa concentração de malato no 
começo da manhã sendo, em ordem decrescente de influência, a temperatura do ar máxima, a temperatura do ar mínima e a RGT.

Uma tendência que é apontada é a correlação positiva entre pluviosidade, umidade relativa do ar máxima e mínima e a correlação negativa destes com a temperatura máxima e mínima. A RGT não demonstra tendência de correlação positiva ou negativa com nenhum dos dois grupos (tabela 9). Na correlação entre as variáveis climáticas a maior correlação é entre os valores de umidade relativa do ar máxima no dia da coleta e a média dos três dias que antecederam a coleta $(0,879)$ e a umidade relativa do ar máxima e mínima dos três dias que antecederam a coleta $(0,749)$.

Na matriz de Spearman M2 não apresentou correlação com as diferentes áreas e inclinações das ilhas de vegetação. M2 também não apresentaram correlação com a posição que a ilha de vegetação ocupa no afloramento rochoso, representado por $\mathrm{X}$ e $\mathrm{Y}$. Porém, o tamanho, a inclinação e a posição influenciaram $M 1$, sendo que o aumento no tamanho da ilha de vegetação levou a uma diminuição na concentração de malato no final da tarde. Quanto mais inclinada a ilha de vegetação, maior o M1. Quanto mas a leste e quanto mais a sul, maior é o M1 (tabela 10). A correlação entre o tamanho, a inclinação e a posição nos eixo oeste-leste e norte-sul não foi maior que 0,50 (tabela 10).

Os resultados de uma GLM-ANOVA para as mesmas variáveis demonstraram coerência com os resultados da matriz de Spearman. M2 e ADAM não foram influenciados, mas M1 foi influenciado pelo tamanho $(5,08 \%)$ e posição da ilha de vegetação no afloramento rochoso, onde o eixo leste-oeste influenciou $9,68 \%$ e o eixo norte-sul influenciou 12,55\% (tabela 7). Na matriz de correlação de Spearman a correlação entre M2 e o ADAM é 0,994 e a correlação entre M1 e ADAM é -0,04 (tabela 10). 
Tabela 3. Resultados do GLM-ANOVA para a comparação entre as classes de precipitação 0,3 e 7 dias ( $N$, média e desvio de ADAM, M1 e M2 para cada classe, $F, P$ e $R^{2} \%$ )

\begin{tabular}{|c|c|c|c|c|c|c|c|c|c|c|}
\hline \multirow[b]{2}{*}{ CPrec0 } & \multicolumn{3}{|c|}{ ADAM } & \multicolumn{3}{|c|}{ M1 } & \multicolumn{4}{|c|}{ M2 } \\
\hline & $\mathrm{N}$ & Média & C.T. & $\mathrm{N}$ & Média & D.P C.T. & $\mathrm{N}$ & Média & D.P & C.T. \\
\hline 1 & 283 & 232.7 & 69.9 & 285 & 22.7 & 5.8 & 284 & 255.6 & 70.1 & $A$ \\
\hline 2 & 82 & 254.0 & 60.4 & 81 & 20.4 & 5.6 & 82 & 274.6 & 60.2 & B \\
\hline GLM & $F=6.26$ & $P=0.013$ & $R^{2}=1.42 \%$ & $F=10.65$ & $P=0.001$ & $\mathrm{R}^{2}=2.58 \%$ & $F=5.01$ & $P=0.026$ & $\mathrm{R}^{2}=1$ & $.09 \%$ \\
\hline CPrec3 & $\mathrm{N}$ & Média & C.T. & $\mathrm{N}$ & Média & D.P C.T. & $\mathrm{N}$ & Média & D.P & C.T. \\
\hline 1 & 324 & 233.9 & 69.6 & 326 & 22.3 & 5.7 & 325 & 256.3 & 69.6 & $A$ \\
\hline 2 & 41 & 265.6 & 49.7 & 40 & 21.4 & 6.6 & 41 & 287.6 & 50.2 & $B$ \\
\hline GLM & $F=7.98$ & $P=0.005$ & $\mathrm{R}^{2}=1.88 \%$ & $F=0.79$ & $P=0.375$ & $\mathrm{R}^{2}=0 \%$ & $\mathrm{~F}=7.73$ & $P=0.006$ & $\mathrm{R} 2=1$ & $1.81 \%$ \\
\hline CPrec7 & $\mathrm{N}$ & Média & C.T. & $\mathrm{N}$ & Média & D.P C.T. & $\mathrm{N}$ & Média & D.P & C.T. \\
\hline 1 & 283 & 228.8 & 70.9 & 286 & 22.3 & 5.7 & 284 & 251.2 & 71.0 & $A$ \\
\hline 2 & 82 & 267.3 & 48.1 & 80 & 21.8 & 6.2 & 82 & 289.6 & 48.3 & B \\
\hline GLM & $F=21.26$ & $P<.001$ & $R^{2}=5.27 \%$ & $F=0.57$ & $P=0.451$ & $R^{2}=0 \%$ & $\mathrm{~F}=21.11$ & $\mathrm{P}<.001$ & $R^{2}=5$. & $.22 \%$ \\
\hline
\end{tabular}


Tabela 4 - Resultados do GLM-ANOVA para a comparação entre as classes de umidade relativa máxima e mínima ao 0, 3 e 7 dias ( $N$, média e desvio de ADAM, M1 e M2 para cada classe, $F, P$ e $R^{2} \%$ )

\begin{tabular}{|c|c|c|c|c|c|c|c|c|c|}
\hline \multirow[b]{2}{*}{ CURMax0 } & \multicolumn{3}{|c|}{ ADAM } & \multicolumn{3}{|c|}{ M1 } & \multicolumn{3}{|c|}{ M2 } \\
\hline & $\mathrm{N}$ & Média & D.P. C.T. & $\mathrm{N}$ & Média & D.P. C.T. & $\mathrm{N}$ & Média & D.P. \\
\hline 1 & 41 & 220.6 & $51.8 \quad A B$ & 41 & 24.2 & 5.7 & 41 & 244.8 & $51.7 \mathrm{AB}$ \\
\hline 2 & 40 & 248.8 & 56.8 & 41 & 22.2 & 3.7 & 41 & 270.8 & 55.8 \\
\hline 3 & 40 & 200.1 & 52.0 & 41 & 26.7 & 5.0 & 40 & 226.6 & 52.5 \\
\hline 4 & 244 & 244.6 & 72.5 & 243 & 21.1 & 5.8 & 244 & 266.0 & 73.2 \\
\hline GLM & $F=6.33$ & $\mathrm{P}<.001$ & $\mathrm{R}^{2}=4.21 \%$ & $F=14.09$ & $\mathrm{P}<.001$ & $\mathrm{R}^{2}=9.71 \%$ & $F=4.97$ & $P=.002$ & $\mathrm{R}^{2}=3.16 \%$ \\
\hline URMax3 & $\mathrm{N}$ & Média & D.P. C.T. & $\mathrm{N}$ & Média & D.P. C.T. & $\mathrm{N}$ & Média & D.P. C.T \\
\hline 1 & 41 & 220.6 & $51.8 \quad \mathrm{BC}$ & 41 & 24.2 & 5.7 & 41 & 244.8 & $51.7 \quad B C$ \\
\hline 2 & 80 & 224.4 & 59.4 & 82 & 24.4 & 4.9 & 81 & 249.0 & $58.3 \quad$ B \\
\hline 3 & 81 & 195.6 & 56.6 & 82 & 20.0 & 5.6 & 81 & 215.5 & 56.3 \\
\hline 4 & 163 & 268.9 & $67.2 \mathrm{~A}$ & 161 & 21.6 & 5.8 & 163 & 291.1 & $67.5 \mathrm{~A}$ \\
\hline SLM & $F=28.81$ & $\mathrm{P}<.001$ & $R^{2}=18.64 \%$ & $F=10.91$ & $\mathrm{P}<.001$ & $\mathrm{R}^{2}=7.53 \%$ & $F=29.66$ & $\mathrm{P}<.001$ & $R^{2}=19.06 \%$ \\
\hline CURMax7 & $\mathrm{N}$ & Média & D.P. C.T. & $\mathrm{N}$ & Média & D.P. C.T. & $\mathrm{N}$ & Média & D.P. C.T \\
\hline 1 & 81 & 284.1 & $70.6 \quad A$ & 80 & 22.9 & $5.8 \mathrm{~A}$ & 81 & 307.7 & $70.8 \mathrm{~A}$ \\
\hline 2 & 121 & 223.1 & 56.8 & 123 & 24.4 & 5.2 & 122 & 247.6 & 56.0 \\
\hline 3 & 122 & 210.2 & 64.0 & 123 & 19.6 & 5.4 & 122 & 229.7 & 63.2 \\
\hline 4 & 41 & 269.0 & $47.1 \quad \mathrm{~A}$ & 40 & 22.1 & $5.9 A B$ & 41 & 291.6 & $46.8 \mathrm{~A}$ \\
\hline GLM & $F=29.21$ & $\mathrm{P}<.001$ & $R^{2}=18.86 \%$ & $F=16.46$ & $\mathrm{P}<.001$ & $R^{2}=11.28 \%$ & $F=31.79$ & $\mathrm{P}<.001$ & $R^{2}=20.2 \%$ \\
\hline CURMino & $\mathrm{N}$ & Média & D.P. C.T. & $\mathrm{N}$ & Média & D.P. C.T. & $\mathrm{N}$ & Média & D.P. C.T \\
\hline 1 & 40 & 200.1 & 52.0 & 41 & 26.7 & 5.0 & 40 & 226.6 & 52.5 \\
\hline 2 & 163 & 225.3 & 59.8 & 164 & 20.5 & 5.5 & 164 & 245.9 & 59.7 \\
\hline 3 & 81 & 284.1 & 70.6 & 80 & 22.9 & 5.8 & 81 & 307.7 & 70.8 \\
\hline 4 & 81 & 233.9 & 67.1 & 81 & 22.5 & 5.4 & 81 & 256.6 & 66.8 \\
\hline GLM & $F=21.42$ & $\mathrm{P}<.001$ & $\mathrm{R}^{2}=14.4 \%$ & $F=14.66$ & $\mathrm{P}<.001$ & $R^{2}=10.09 \%$ & $F=21.87$ & $P<.001$ & $R^{2}=14.64 \%$ \\
\hline CURMin3 & $\mathrm{N}$ & Média & D.P. C.T. & $\mathrm{N}$ & Média & D.P. C.T. & $\mathrm{N}$ & Média & D.P. C.T \\
\hline 1 & 81 & 220.7 & $58.5 \quad B$ & 82 & 19.6 & $\begin{array}{ll}4.8 \quad B \\
\end{array}$ & 82 & 240.6 & 59.2 \\
\hline 2 & 161 & 230.3 & 77.0 & 163 & 24.6 & 5.2 & 161 & 255.0 & 76.9 \\
\hline 3 & 82 & 254.0 & 60.4 & 81 & 20.4 & 5.6 & 82 & 274.6 & $60.2 A B$ \\
\hline 4 & 41 & 265.6 & 49.7 & 40 & 21.4 & 6.6 & 41 & 287.6 & $50.2 \mathrm{~A}$ \\
\hline GLM & $F=6.4$ & $\mathrm{P}<.001$ & $\mathrm{R}^{2}=4.26 \%$ & $F=20.16$ & $\mathrm{P}<.001$ & $R^{2}=13.6 \%$ & $F=6.21$ & $\mathrm{P}<.001$ & $\mathrm{R}^{2}=4.1 \%$ \\
\hline CURMin7 & $\mathrm{N}$ & Média & D.P. C.T. & $\mathrm{N}$ & Média & D.P. C.T. & $\mathrm{N}$ & Média & D.P. C.T \\
\hline 1 & 121 & 247.3 & $80.7 \quad A B$ & 122 & 23.3 & $5.8 \quad A$ & 121 & 270.7 & $80.3 \mathrm{AB}$ \\
\hline 2 & 122 & 219.1 & 63.5 & 122 & 20.5 & 5.9 & 122 & 239.7 & 64.0 \\
\hline 3 & 81 & 234.5 & 55.9 & 82 & 23.2 & 4.9 & 82 & 257.8 & 55.0 BC \\
\hline 4 & 41 & 269.0 & $47.1 \quad \mathrm{~A}$ & 40 & 22.1 & $5.9 \quad A B$ & 41 & 291.6 & $46.8 \quad \mathrm{~A}$ \\
\hline GLM & $F=7.04$ & $\mathrm{P}<.001$ & $\mathrm{R}^{2}=4.74 \%$ & $F=6.02$ & $P=0.001$ & $R^{2}=3.96 \%$ & $F=7.95$ & $\mathrm{P}<.001$ & $\mathrm{R}^{2}=5.4 \%$ \\
\hline
\end{tabular}


Tabela 5 - Resultados do GLM-ANOVA para a comparação entre as classes de temperatura máxima e mínima aos 0, 3 e 7 dias ( $N$, média e desvio de ADAM, M1 e M2 para cada classe, F, P e $R^{2} \%$ )

\begin{tabular}{|c|c|c|c|c|c|c|c|c|c|}
\hline \multirow[b]{2}{*}{ CTMax0 } & \multicolumn{3}{|c|}{ ADAM } & \multicolumn{3}{|c|}{ M1 } & \multicolumn{3}{|c|}{ M2 } \\
\hline & $\mathrm{N}$ & Média & D.P. C.T. & $\mathrm{N}$ & Média & D.P. C.T. & $\mathrm{N}$ & Média & D.P. C.T. \\
\hline 1 & 41 & 265.6 & $49.7 \mathrm{~A}$ & 40 & 21.4 & 6.6 & 41 & 287.6 & $50.2 \mathrm{~A}$ \\
\hline 2 & 161 & 254.8 & $74.5 \mathrm{~A}$ & 162 & 22.9 & 4.9 & 162 & 277.9 & 74.3 \\
\hline 3 & 163 & 213.3 & $57.7 \quad B$ & 164 & 21.7 & 6.3 & 163 & 234.9 & 57.4 \\
\hline GLM & $F=20.83$ & $P<.001$ & $R^{2}=9.83 \%$ & $F=2.37$ & $P=.095$ & $\mathrm{R}^{2}=0.75 \%$ & $F=22.14$ & $P<.001$ & $R^{2}=10.38 \%$ \\
\hline СТМах3 & $\mathrm{N}$ & Média & D.P. C.T. & $\mathrm{N}$ & Média & D.P. C.T. & $\mathrm{N}$ & Média & D.P. C.T. \\
\hline 1 & 41 & 265.6 & $49.7 \quad A$ & 40 & 21.4 & $6.6 \quad B$ & 41 & 287.6 & $50.2 \mathrm{~A}$ \\
\hline 2 & 122 & 226.8 & 62.4 & 123 & 19.3 & 4.8 & 123 & 246.3 & 62.3 \\
\hline 3 & 202 & 238.2 & 73.5 & 203 & 24.1 & 5.4 & 202 & 262.5 & $73.2 A B$ \\
\hline GLM & $F=5.07$ & $P=.007$ & $\mathrm{R}^{2}=2.19 \%$ & $F=30.61$ & $P<.001$ & $R^{2}=13.96 \%$ & $F=6.09$ & $P=.002$ & $\mathrm{R}^{2}=2.71 \%$ \\
\hline CTMax7 & $\mathrm{N}$ & Média & D.P. C.T. & $\mathrm{N}$ & Média & D.P. C.T. & $\mathrm{N}$ & Média & D.P. C.T. \\
\hline 1 & 122 & 236.9 & $59.3 \mathrm{~A}$ & 122 & 20.4 & $\begin{array}{ll}5.3 \quad \mathrm{~B} \\
\end{array}$ & 123 & 257.6 & $60.2 \quad A$ \\
\hline 2 & 82 & 243.1 & $55.3 \mathrm{~A}$ & 81 & 22.8 & 6.3 & 82 & 266.2 & 55.0 \\
\hline 3 & 161 & 235.0 & $80.0 \mathrm{~A}$ & 163 & 23.2 & 5.6 & 161 & 258.3 & $79.7 \quad A$ \\
\hline GLM & $F=0.38$ & $P=.681$ & $R^{2}=0 \%$ & $F=8.78$ & $\mathrm{P}<.001$ & $R^{2}=4.09 \%$ & $F=0.45$ & $P=.635$ & $\mathrm{R}^{2}=0 \%$ \\
\hline CTmino & $\mathrm{N}$ & Média & D.P. C.T. & $\mathrm{N}$ & Média & D.P. C.T. & $\mathrm{N}$ & Média & D.P. C.T. \\
\hline 1 & 82 & 252.3 & $61.0 \mathrm{~A}$ & 81 & 20.0 & $5.9 \quad B$ & 82 & 272.6 & $61.0 \mathrm{~A}$ \\
\hline 2 & 242 & 235.3 & $72.4 \quad A B$ & 244 & 22.6 & 5.6 & 243 & 258.1 & 72.6 \\
\hline 3 & 41 & 220.6 & $51.8 \quad$ B & 41 & 24.2 & 5.7 & 41 & 244.8 & 51.7 A \\
\hline GLM & $\mathrm{F}=3.35$ & $P=.036$ & $\mathrm{R}^{2}=1.27 \%$ & $F=9.0$ & $\mathrm{P}<.001$ & $R^{2}=4.2 \%$ & $F=2.53$ & $P=.081$ & $\mathrm{R}^{2}=0.83 \%$ \\
\hline CTmin 3 & $\mathrm{~N}$ & Média & D.P. C.T. & $\mathrm{N}$ & Média & D.P. C.T. & $\mathrm{N}$ & Média & D.P. C.T. \\
\hline 1 & 122 & 235.8 & $59.5 \mathrm{~A}$ & 122 & 20.2 & $5.5 \quad C$ & 123 & 256.3 & $60.4 \mathrm{~A}$ \\
\hline 2 & 121 & 246.6 & $84.3 \mathrm{~A}$ & 122 & 22.0 & 5.4 & 121 & 268.8 & 84.4 \\
\hline 3 & 122 & 230.1 & $57.7 \mathrm{~A}$ & 122 & 24.3 & 5.8 & 122 & 254.6 & $57.0 \quad \mathrm{~A}$ \\
\hline GLM & $\mathrm{F}=1.82$ & $P=.164$ & $\mathrm{R}^{2}=0.45 \%$ & $F=16.83$ & $P<.001$ & $R^{2}=7.98 \%$ & $F=1.57$ & $P=.209$ & $\mathrm{R}^{2}=0.31 \%$ \\
\hline CTmin 7 & $\mathrm{~N}$ & Média & D.P. C.T. & $\mathrm{N}$ & Média & D.P. C.T. & $\mathrm{IN}$ & Média & D.P. C.T. \\
\hline 1 & 81 & 220.7 & $58.5 \quad$ B & 82 & 19.6 & $4.8 \quad B$ & 82 & 240.6 & $59.2 \quad B$ \\
\hline 2 & 243 & 245.9 & $72.4 \quad \mathrm{~A}$ & 243 & 22.7 & 5.8 & 243 & 268.9 & $72.1 \quad A$ \\
\hline 3 & 41 & 220.6 & $51.8 \quad A B$ & 41 & 24.2 & $5.7 \quad A$ & 41 & 244.8 & $51.7 \quad A B$ \\
\hline GLM & $F=5.69$ & $P=.004$ & $\mathrm{R}^{2}=2.51 \%$ & $F=12.1$ & $\mathrm{P}<.001$ & $R^{2}=5.73 \%$ & $F=6.54$ & $P=.002$ & $\mathrm{R}^{2}=2.95 \%$ \\
\hline
\end{tabular}


Tabela 6 - Resulta dos do GLM-ANOVA para a comparação entre as classes de irradiância ( $N$, média e desvio de ADAM, M1 e M2 para cada classe, F, P e $R^{2} \%$ )

\begin{tabular}{|c|c|c|c|c|c|c|c|c|c|c|}
\hline \multirow[b]{2}{*}{ CRGTO } & \multicolumn{4}{|c|}{ ADAM } & \multicolumn{3}{|c|}{ M1 } & \multicolumn{3}{|c|}{ M2 } \\
\hline & $\mathrm{N}$ & Média & D.P. & C.T. & $\mathrm{N}$ & Média & D.P. C.T. & $\mathrm{N}$ & Média & D.P. C.T. \\
\hline 1 & 162 & 253,2 & 71,8 & $A$ & 162 & 21,4 & $5,4 \quad B$ & 163 & 275,0 & $72,9 \quad A$ \\
\hline 2 & 162 & 214,6 & 61,8 & B & 164 & 23,1 & 5,9 & 162 & 237,6 & 61,0 \\
\hline 3 & 341 & 265,6 & 49,7 & A & 40 & 21,4 & $6,6 \quad A B$ & 41 & 287,6 & $50,2 \quad A$ \\
\hline GLM & $F=18.48$ & $P<.001$ & $\mathrm{R}^{2}=8$. & $76 \%$ & $F=3.91$ & $P=0.021$ & $\mathrm{R}^{2}=1.57 \%$ & $F=17.33$ & $P<.001$ & $\mathrm{R}^{2}=8.21 \%$ \\
\hline CRGT3 & $\mathrm{N}$ & Média & D.P. & C.T. & $\mathrm{N}$ & Média & D.P. C.T. & $\mathrm{N}$ & Média & D.P. C.T. \\
\hline 1 & 40 & 303,0 & 83,4 & $A$ & 40 & 24,5 & $4,6 \quad A$ & 40 & 328,3 & $82,7 \quad A$ \\
\hline 2 & 163 & 255,6 & 57,0 & B & 162 & 21,1 & 5,5 & 164 & 276,9 & 56,8 \\
\hline 3 & 162 & 203,0 & 55,0 & C & 164 & 22,7 & 6,1 & 162 & 225,7 & 55,2 \\
\hline GLM & $F=58.85$ & $P<.001$ & $R^{2}=24$ & $.12 \%$ & $F=6.92$ & $\mathrm{P}<.001$ & $\mathrm{R}^{2}=3.14 \%$ & $F=60.04$ & $P<.001$ & $\mathrm{R}^{2}=24.44 \%$ \\
\hline CRGT7 & $\mathrm{N}$ & Média & D.P. & C.T. & $\mathrm{N}$ & Média & D.P. C.T. & $\mathrm{N}$ & Média & D.P. C.T. \\
\hline 1 & 81 & 259,0 & 52,8 & $A$ & 81 & 22,2 & $4,9 \quad A B$ & 82 & 281,2 & $52,2 \quad A$ \\
\hline 2 & 203 & 230,6 & 75,1 & B & 204 & 21,5 & 5,8 & 203 & 252,1 & $75,6 \quad B$ \\
\hline 3 & 81 & 233,3 & 60,3 & B & 81 & 24,1 & 6,4 & 81 & 257,5 & $59,5 \quad A B$ \\
\hline GLM & $F=5.33$ & $P<.001$ & $\mathrm{R}^{2}=2.3$ & $32 \%$ & $F=6.11$ & $P=0.002$ & $\mathrm{R}^{2}=2.72 \%$ & $F=5.48$ & $P=0.005$ & $\mathrm{R}^{2}=2.39 \%$ \\
\hline
\end{tabular}


Tabela 7. Resultados do GLM-ANOVA para a comparação entre as classes de Área, Inclinação, variação espacial $X$ e $Y\left(N\right.$, média e desvio de ADAM, M1 e M2 para cada classe, $F, P$ e $R^{2} \%$ )

\begin{tabular}{|c|c|c|c|c|c|c|c|c|c|c|c|}
\hline \multirow[b]{2}{*}{ CArea } & \multicolumn{4}{|c|}{ ADAM } & \multicolumn{4}{|c|}{ M1 } & \multicolumn{3}{|c|}{ M2 } \\
\hline & $\mathrm{N}$ & Média & D.P & C.T. & $\mathrm{N}$ & Média & D.P & C.T. & $\mathrm{N}$ & Média & D.P \\
\hline 1 & 89 & 229.7 & 67.5 & $A$ & 88 & 24.5 & 5.4 & $A$ & 90 & 255.1 & $68.0 \mathrm{~A}$ \\
\hline 2 & 92 & 236.6 & 71.7 & A & 92 & 21.0 & 5.5 & B & 92 & 257.6 & $71.9 \mathrm{~A}$ \\
\hline 3 & 92 & 235.4 & 64.4 & A & 92 & 22.3 & 5.7 & $A B$ & 92 & 257.7 & $64.5 \mathrm{~A}$ \\
\hline 4 & 92 & 248.0 & 69.4 & A & 94 & 21.0 & 5.9 & B & 92 & 268.8 & $69.3 \mathrm{~A}$ \\
\hline \multicolumn{2}{|c|}{ GLM F=1.15 } & $P=0.331$ & \multicolumn{2}{|c|}{$R^{2}=0.12 \%$} & $F=7.52$ & $P<0.001$ & \multicolumn{2}{|c|}{$R^{2}=5.08 \%$} & $F=0.73$ & \multicolumn{2}{|c|}{$P=0.536 R^{2}=0.00 \%$} \\
\hline Clncl & $\mathrm{N}$ & Média & D.P & C.T. & $\mathrm{N}$ & Média & D.P & C.T. & $\mathrm{N}$ & Média & D.P \\
\hline 1 & 91 & 232.4 & 68.3 & $A$ & 91 & 21.8 & 6.2 & $A$ & 91 & 254.2 & $67.3 \mathrm{~A}$ \\
\hline 2 & 90 & 234.2 & 68.4 & $A$ & 91 & 23.0 & 6.0 & A & 90 & 257.2 & $68.7 \mathrm{~A}$ \\
\hline 3 & 90 & 244.9 & 63.4 & $A$ & 91 & 21.4 & 5.7 & $A$ & 91 & 266.7 & $62.6 \mathrm{~A}$ \\
\hline 4 & 94 & 238.4 & 73.2 & A & 93 & 22.6 & 5.3 & A & 94 & 261.2 & $74.7 \mathrm{~A}$ \\
\hline GLM & $\mathrm{F}=0.6$ & \multicolumn{3}{|c|}{$P=0.615 R^{2}=0.00 \%$} & $F=1.46$ & \multicolumn{3}{|c|}{$P=0.226 R^{2}=0.37 \%$} & $F=0.56$ & \multicolumn{2}{|c|}{$5 \mathrm{P}=0.639 \mathrm{R}^{2}=0.00 \%$} \\
\hline CX & $\mathrm{N}$ & Média & D.P & C.T. & $\mathrm{N}$ & Média & D.P & C.T. & $\mathrm{N}$ & Média & D.P $\quad$ C.T \\
\hline 1 & 120 & 235.5 & 69.0 & $A$ & 121 & 23.7 & 5.2 & $A$ & 120 & 259.5 & $69.6 \mathrm{~A}$ \\
\hline 2 & 122 & 233.4 & 66.6 & A & 122 & 23.3 & 5.8 & A & 123 & 257.0 & $66.6 \mathrm{~A}$ \\
\hline 3 & 123 & 243.4 & 69.6 & A & 123 & 19.6 & 5.4 & B & 123 & 263.1 & $69.4 \mathrm{~A}$ \\
\hline \multicolumn{2}{|l|}{ GLM } & \multicolumn{3}{|c|}{$P=0.487 R^{2}=0.00 \%$} & $F=20.57$ & \multicolumn{3}{|c|}{$P<0.001 R^{2}=9.68 \%$} & $F=0.25$ & \multicolumn{2}{|c|}{$\mathrm{P}=0.782 \mathrm{R}^{2}=0.00 \%$} \\
\hline $\mathrm{CY}$ & $\mathrm{N}$ & Média & D.P & C.T. & $\mathrm{N}$ & Média & D.P & C.T. & $\mathrm{N}$ & Média & D.P \\
\hline 1 & 72 & 227.3 & 77.4 & $A$ & 71 & 22.9 & 5.3 & $A$ & 72 & 250.5 & $78.3 \mathrm{~A}$ \\
\hline 2 & 73 & 243.2 & 67.1 & A & 74 & 19.5 & 5.1 & B & 73 & 262.4 & $66.9 \mathrm{~A}$ \\
\hline 3 & 74 & 245.7 & 63.8 & A & 74 & 20.0 & 5.4 & B & 74 & 265.6 & $64.0 \mathrm{~A}$ \\
\hline 4 & 72 & 225.5 & 72.9 & A & 73 & 24.2 & 5.5 & $A$ & 72 & 250.1 & $73.8 \mathrm{~A}$ \\
\hline 5 & 74 & 245.2 & 58.3 & $A$ & 74 & 24.5 & 5.9 & $A$ & 75 & 270.0 & $57.1 \mathrm{~A}$ \\
\hline \multicolumn{2}{|c|}{ GLM F= } & \multicolumn{3}{|c|}{$P=0.178 R^{2}=0.64 \%$} & $F=14.1$ & \multicolumn{3}{|c|}{$P<0.001 R^{2}=12.55 \%$} & $F=1.28$ & \multicolumn{2}{|c|}{$P=0.278 R^{2}=0.30 \%$} \\
\hline
\end{tabular}


Tabela 8 - Valores de r e significância para as correlações de Spearman entre as variáveis resposta e as variáveis climáticas. Ver Tabela 1 (Material e Métodos) para a descrição das variáveis.

\begin{tabular}{|c|c|c|c|c|c|c|c|c|c|}
\hline \multicolumn{2}{|l|}{ Variáveis } & ADAM & M1 & M2 & & & ADAM & M1 & M2 \\
\hline \multirow[t]{2}{*}{ Prec0 } & Spearman &, $166^{* *}$ &,$- 186^{* *}$ &, $152^{* *}$ & Tmax0 & Spearman &,$- 239 * *$ & 0,08 &,$- 230 * *$ \\
\hline & $\mathrm{p}$ & 0,00 & 0,00 & 0,00 & & $\mathrm{p}$ & 0,00 & 0,14 & 0,00 \\
\hline \multirow[t]{2}{*}{ Prec3 } & Spearman &, $167^{* *}$ &,$- 158^{* *}$ &, $152^{* *}$ & Tmax3 & Spearman &,$- 138 * *$ & ,339** &,$- 108 *$ \\
\hline & $\mathrm{p}$ & 0,00 & 0,00 & 0,00 & & $\mathrm{p}$ & 0,01 & 0,00 & 0,04 \\
\hline \multirow[t]{2}{*}{ Prec7 } & Spearman & $-0,01$ &,$- 203^{* *}$ & $-0,03$ & Tmax 7 & Spearman & 0,01 & 0,05 & 0,01 \\
\hline & $\mathrm{p}$ & 0,85 & 0,00 & 0,59 & & $\mathrm{p}$ & 0,92 & 0,31 & 0,80 \\
\hline \multirow[t]{2}{*}{ URmaxo } & Spearman &, $125^{*}$ &,$- 255^{* *}$ & ,105* & Tmino & Spearman &,$- 206 * *$ &, $110^{*}$ &,$- 195^{* *}$ \\
\hline & $\mathrm{p}$ & 0,02 & 0,00 & 0,05 & & $\mathrm{p}$ & 0,00 & 0,03 & 0,00 \\
\hline \multirow[t]{2}{*}{ URmax3 } & Spearman &, $311 * *$ &,$- 203 * *$ &, $296 * *$ & Tmin3 & Spearman & 0,01 &, $313^{* *}$ & 0,04 \\
\hline & $\mathrm{p}$ & 0,00 & 0,00 & 0,00 & & $p$ & 0,85 & 0,00 & 0,47 \\
\hline \multirow[t]{2}{*}{ URmax7 } & Spearman &,$- 158^{* *}$ &,$- 308 * *$ &,$- 186 * *$ & Tmin07 & Spearman & 0,10 &, $111^{*}$ &, $111^{*}$ \\
\hline & $\mathrm{p}$ & 0,00 & 0,00 & 0,00 & & $\mathrm{p}$ & 0,06 & 0,03 & 0,03 \\
\hline \multirow[t]{2}{*}{ URmino } & Spearman &, $238 * *$ & 0,08 &, $244^{* *}$ & RGTO & Spearman &,$- 156^{* *}$ & 0,06 &,$- 150 * *$ \\
\hline & $\mathrm{p}$ & 0,00 & 0,13 & 0,00 & & $\mathrm{p}$ & 0,00 & 0,25 & 0,00 \\
\hline \multirow[t]{2}{*}{ URmin3 } & Spearman &, $328 * *$ & 0,00 & ,329** & RGT3 & Spearman &,$- 453 * *$ & 0,01 &,$- 453^{* *}$ \\
\hline & $p$ & 0,00 & 0,95 & 0,00 & & $\mathrm{p}$ & 0,00 & 0,86 & 0,00 \\
\hline \multirow[t]{2}{*}{ URmin7 } & Spearman & $-0,02$ & $-0,07$ & $-0,02$ & RGT7 & Spearman &,$- 118^{*}$ &, $112 *$ &,$- 107^{*}$ \\
\hline & $p$ & 0,77 & 0,21 & 0,65 & & $\mathrm{p}$ & 0,02 & 0,03 & 0,04 \\
\hline
\end{tabular}


Tabela 9 - Valores de $r$ e significância para as correlações de Spearman entre as variáveis locais e as variáveis climáticas. Ver Tabela 1 (Material e Métodos) para a descrição das variáveis

\begin{tabular}{|c|c|c|c|c|c|c|c|c|}
\hline \multirow[t]{2}{*}{ Variáveis } & & Preco & Prec3 & Prec7 & URmax 0 & URmax3 & URmax 7 & URmino \\
\hline & \multicolumn{8}{|l|}{ Spearman r } \\
\hline \multirow[t]{2}{*}{ Prec0 } & $p$ & & & & & & & \\
\hline & Spearman $r$ &, $385^{* *}$ & & & & & & \\
\hline \multirow[t]{2}{*}{ Prec3 } & $\mathrm{p}$ & 0,00 & & & & & & \\
\hline & Spearman $r$ &, $316^{* *}$ &, $334 * *$ & & & & & \\
\hline \multirow[t]{2}{*}{ Prec7 } & $\mathrm{p}$ & 0,00 & 0,00 & & & & & \\
\hline & Spearman $r$ &, $369 * *$ & ,116* &, $232 * *$ & & & & \\
\hline \multirow[t]{2}{*}{ URmax0 } & $p$ & 0,00 & 0,03 & 0,00 & & & & \\
\hline & Spearman $r$ &, $541^{* *}$ &, $245^{* *}$ &, $230 * *$ &, $879 * *$ & & & \\
\hline \multirow[t]{2}{*}{ URmax3 } & $\mathrm{p}$ & 0,00 & 0,00 & 0,00 & 0,00 & & & \\
\hline & Spearman $r$ & $621^{* *}$ & 0,09 &, $458^{* *}$ &, $248^{* *}$ & 0,08 & & \\
\hline \multirow[t]{2}{*}{ URmax7 } & $\mathrm{p}$ & 0,00 & 0,09 & 0,00 & 0,00 & 0,13 & & \\
\hline & Spearman $r$ &, $104^{*}$ &, $284 * *$ & 0,10 &, $366 * *$ &, $296 * *$ & 0,00 & \\
\hline \multirow[t]{2}{*}{ URmino } & $p$ & 0,05 & 0,00 & 0,05 & 0,00 & 0,00 & 1,00 & \\
\hline & Spearman $r$ &, $518^{* *}$ &, $461^{* *}$ &, $424 * *$ &, $465^{* *}$ &, $749 * *$ &,$- 167 * *$ &, $267^{* *}$ \\
\hline \multirow[t]{2}{*}{ URmin3 } & $\mathrm{p}$ & 0,00 & 0,00 & 0,00 & 0,00 & 0,00 & 0,00 & 0,00 \\
\hline & Spearman $r$ &, $104 *$ &, $177^{* *}$ &, $627^{* *}$ &,$- 366^{* *}$ &,$- 357 * *$ &, $483^{* *}$ &, $150 * *$ \\
\hline \multirow[t]{2}{*}{ URmin7 } & $p$ & 0,05 & 0,00 & 0,00 & 0,00 & 0,00 & 0,00 & 0,00 \\
\hline & Spearman $r$ &,$- 104 *$ &,$- 514 * *$ &,$- 170 * *$ &,$- 554 * *$ &,$- 496 * *$ & $-0,02$ &,$- 683^{* *}$ \\
\hline \multirow[t]{2}{*}{ Tmax0 } & $\mathrm{p}$ & 0,05 & 0,00 & 0,00 & 0,00 & 0,00 & 0,75 & 0,00 \\
\hline & Spearman $r$ &,$- 104 *$ &,$- 293 * *$ &,$- 271 * *$ &,$- 396 * *$ &,$- 470 * *$ &,$- 133^{*}$ &, $250 * *$ \\
\hline \multirow[t]{2}{*}{ Tmax3 } & $p$ & 0,05 & 0,00 & 0,00 & 0,00 & 0,00 & 0,01 & 0,00 \\
\hline & Spearman $r$ &, $104 *$ & 0,05 &,$- 407 * *$ & ,396** &, $383 * *$ &,$- 350 * *$ & 0,05 \\
\hline \multirow[t]{2}{*}{ Tmax7 } & $\mathrm{p}$ & 0,05 & 0,31 & 0,00 & 0,00 & 0,00 & 0,00 & 0,34 \\
\hline & Spearman $r$ &,$- 207 * *$ &,$- 692 * *$ &, $136 * *$ &,$- 485^{* *}$ &,$- 522 * *$ &, $150 * *$ &,$- 317^{* *}$ \\
\hline \multirow[t]{2}{*}{ Tmino } & $\mathrm{p}$ & 0,00 & 0,00 & 0,01 & 0,00 & 0,00 & 0,00 & 0,00 \\
\hline & Spearman $r$ &, $207^{* *}$ &,$- 293 * *$ & $-0,02$ &,$- 396 * *$ &,$- 287 * *$ & 0,02 & ,200** \\
\hline \multirow[t]{2}{*}{ Tmin3 } & $\mathrm{p}$ & 0,00 & 0,00 & 0,75 & 0,00 & 0,00 & 0,75 & 0,00 \\
\hline & Spearman $r$ &, $104 *$ &, $257^{* *}$ & $-0,08$ & $-0,08$ &, $122 *$ &,$- 450 * *$ & 0,03 \\
\hline \multirow[t]{2}{*}{ Tmin07 } & $p$ & 0,05 & 0,00 & 0,10 & 0,13 & 0,02 & 0,00 & 0,52 \\
\hline & Spearman $r$ &,$- 207 * *$ &, $372 * *$ &, $441 * *$ &,$- 109 *$ &,$- 131^{*}$ &,$- 283^{* *}$ & $-0,08$ \\
\hline \multirow[t]{2}{*}{ RGTO } & $p$ & 0,00 & 0,00 & 0,00 & 0,04 & 0,01 & 0,00 & 0,11 \\
\hline & Spearman $r$ &,$- 414^{* *}$ &,$- 231 * *$ &, $237^{* *}$ &,$- 317^{* *}$ &,$- 540 * *$ & 0,03 &,$- 567 * *$ \\
\hline \multirow[t]{2}{*}{ RGT3 } & $p$ & 0,00 & 0,00 & 0,00 & 0,00 & 0,00 & 0,52 & 0,00 \\
\hline & Spearman $r$ &,$- 311^{* *}$ &, $293^{* *}$ & $-0,02$ & 0,06 & 0,02 &,$- 533^{* *}$ &,$- 117^{*}$ \\
\hline RGT7 & $\mathrm{p}$ & 0,00 & 0,00 & 0,75 & 0,25 & 0,74 & 0,00 & 0,03 \\
\hline
\end{tabular}


Tabela 9 Continuação - Valores de r e significância para as correlações de Spearman entre as variáveis locais e as variáveis climáticas. Ver Tabela 1 (Material e Métodos) para a descrição das variáveis.

\begin{tabular}{|c|c|c|c|c|c|c|c|c|c|c|c|}
\hline & URmin3 & URmin7 & Tmax0 & Tmax3 & Tmax7 & $\operatorname{Tmin} 0$ & $\operatorname{Tmin} 3$ & Tmin 07 & RGTO & RGT3 & RGT7 \\
\hline &,$- 167^{* *}$ & & & & & & & & & & \\
\hline \multirow[t]{2}{*}{ URmin7 } & 0,00 & & & & & & & & & & \\
\hline &,$- 333 * *$ & $-0,03$ & & & & & & & & & \\
\hline \multirow[t]{2}{*}{ Tmax0 } & 0,00 & 0,52 & & & & & & & & & \\
\hline &,$- 167 * *$ & $-0,05$ &, $400 * *$ & & & & & & & & \\
\hline \multirow[t]{2}{*}{ Tmax3 } & 0,00 & 0,34 & 0,00 & & & & & & & & \\
\hline &, $350 * *$ &,$- 883^{* *}$ & 0,05 & ,283** & & & & & & & \\
\hline \multirow[t]{2}{*}{ Tmax7 } & 0,00 & 0,00 & 0,34 & 0,00 & & & & & & & \\
\hline &,$- 400 * *$ &, $400 * *$ &, $767^{* *}$ &, $433^{* *}$ &,$- 383 * *$ & & & & & & \\
\hline \multirow[t]{2}{*}{ Tmino } & 0,00 & 0,00 & 0,00 & 0,00 & 0,00 & & & & & & \\
\hline & 0,08 &, $200 * *$ & $450 * *$ &, $850 * *$ & 0,03 &, $583 * *$ & & & & & \\
\hline \multirow[t]{2}{*}{ Tmin3 } & 0,11 & 0,00 & 0,00 & 0,00 & 0,52 & 0,00 & & & & & \\
\hline &, $483^{* *}$ &,$- 383 * *$ &, $333^{* *}$ &, $417^{* *}$ &, $667^{* *}$ & $-0,03$ &, $367^{* *}$ & & & & \\
\hline \multirow[t]{2}{*}{ Tmin07 } & 0,00 & 0,00 & 0,00 & 0,00 & 0,00 & 0,52 & 0,00 & & & & \\
\hline &, $350 * *$ & $-0,02$ & 0,08 &, $183^{* *}$ &, $267^{* *}$ & $-0,05$ & 0,03 &, $533^{* *}$ & & & \\
\hline \multirow[t]{2}{*}{ RGTO } & 0,00 & 0,75 & 0,11 & 0,00 & 0,00 & 0,34 & 0,52 & 0,00 & & & \\
\hline &,$- 333 * *$ & 0,05 &, $500 * *$ &, $183 * *$ & $-0,02$ &, $417^{* *}$ & $-0,02$ & 0,02 &, $633^{* *}$ & & \\
\hline \multirow[t]{2}{*}{ RGT3 } & 0,00 & 0,34 & 0,00 & 0,00 & 0,75 & 0,00 & 0,75 & 0,75 & 0,00 & & \\
\hline &, $317^{* *}$ &,$- 517 * *$ & $-0,08$ & 0,10 &, $600 * *$ &,$- 400 * *$ &,$- 200 * *$ &, $483^{* *}$ &, $817^{* *}$ &, $483^{* *}$ & \\
\hline RGT7 & 0,00 & 0,00 & 0,11 & 0,05 & 0,00 & 0,00 & 0,00 & 0,00 & 0,00 & 0,00 & \\
\hline
\end{tabular}


Tabela 10 - Valores de r e significância para as correlações de Spearman entre as variáveis resposta e as variáveis explanatórias locais (área ilha, inclinação, x, y).

\begin{tabular}{|c|c|c|c|c|c|c|c|}
\hline & & ADAM & M1 & M2 & LogArea & Incl & $x$ \\
\hline \multirow[t]{2}{*}{ M1 } & Spearman & -0.04 & 1.00 & & & & \\
\hline & $p$ & 0.44 & & & & & \\
\hline \multirow[t]{2}{*}{ M2 } & Spearman &, $994^{\star \star}$ & 0.04 & 1.00 & & & \\
\hline & $p$ & 0.00 & 0.43 & . & & & \\
\hline \multirow[t]{2}{*}{ LogArea } & Spearman & 0.09 &,$- 177^{* *}$ & 0.08 & 1.00 & & \\
\hline & $\mathrm{p}$ & 0.08 & 0.00 & 0.15 & & & \\
\hline \multirow[t]{2}{*}{ Incl } & Spearman & 0.02 &, $104 *$ & 0.04 &,$- 238^{\star \star}$ & 1.00 & \\
\hline & $\mathrm{p}$ & 0.64 & 0.05 & 0.49 & 0.00 & . & \\
\hline \multirow[t]{2}{*}{$X$} & Spearman & 0.08 &,$- 337^{* *}$ & 0.05 &, $379^{\star \star}$ &,$- 477^{\star \star}$ & 1.00 \\
\hline & $p$ & 0.15 & 0.00 & 0.33 & 0.00 & 0.00 & 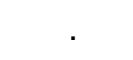 \\
\hline \multirow[t]{2}{*}{$\mathbf{Y}$} & Spearman & 0.08 &, $188^{* *}$ & 0.10 &,$- 111^{*}$ &, $188^{* *}$ &,$- 441^{\star *}$ \\
\hline & $p$ & 0.13 & 0.00 & 0.05 & 0.03 & 0.00 & 0.00 \\
\hline
\end{tabular}




\section{DISCUSSÃO}

Nas plantas CAM a descrição da evolução das trocas gasosas ao longo do dia não permite a visualização da atividade do metabolismo do $\mathrm{CO}_{2}$, pois os estômatos permanecem fechados durante parte do dia enquanto existe atividade metabólica do carbono dentro da folha. Uma forma de descrever os acontecimentos do ciclo do carbono dentro da folha é a titulação de ácidos da folha, fazendo de plantas CAM-obrigatório úteis objetos para o estudo de algumas questões fisiológicas (Kornas et al., 2009). O processo de titulação requer grande volume de matéria vegetal para a confecção de séries temporais relevantes da atividade do ciclo de carbono (Luttge, 2002).

Na fotossíntese tipo CAM, a concentração máxima de malato no mesofilo é alcançada no nascer do sol, quando o malato deixa de ser sintetizado e passa a ser catabolizado, e a concentração mínima de malato no mesofilo é alcançada no pôr do sol, quando os estômatos são abertos iniciando a captura de $\mathrm{CO}_{2}$ atmosférico e o malato novamente passa a ser sintetizado iniciando o ciclo circadiano de carbono. Para estimar a concentração de malato foi realizada uma titulação de extratos do mesofilo. Entretanto, a técnica de titulação da acidez do mesofilo constitui apenas uma aproximação porque, além do malato, existem outros ácidos tituláveis que tem suas concentrações variadas de acordo com as condições climáticas, em especial, o citrato. A função do ciclo do citrato não é clara (Kornas et al., 2009). Esse radical pode estar envolvido diretamente com o processo de proteção contra a fotoinibição (Kornas et al., 2009). Luttge (2007) sugeriu que o ciclo circadiano de citrato e a utilização de $\mathrm{CO}_{2}$ provindo da respiração em situações de estresse podem contribuir para dissipar a energia de excitação provinda do trabalho fotoquímico de refixação de $\mathrm{CO}_{2}$. Kornas et al. (2009) sugeriu que o citrato pode ter um papel secundário como fonte de carbono para o ciclo de Calvin na fase III do CAM, e o 
decréscimo nos níveis de citrato pode estar relacionado com a atividade da via bioquímica respiratória e equilíbrio de oxi-redução celular. As interpretações dos resultados desse trabalho aceitam que a variação da concentração de ácidos tituláveis do mesofilo reflete, principalmente, a variação de concentração do malato.

Espera-se que o acúmulo de malato siga o padrão de disponibilidade hídrica (Szarek \& Ting, 1974) para a planta. Mas em um grupo evolutivamente e fisiologicamente tão diverso como o das plantas CAM, diferentes espécies podem apresentar diferentes respostas fisiológicas, principalmente relacionadas à capacidade de suportar o estresse hídrico. Em Drymoglossum piloselloides e Pyrrosia longifolia, duas espécies CAM obrigatório, um período de 24 horas sem rega já causa diminuição da tomada noturna de $\mathrm{CO}_{2}$. Em cinco dias de seca a planta já apresenta sinais de estresse hídrico severo e seis dias cessa a tomada noturna (Ong et al., 1986). Entretanto, em Xorisicyos sanguyi (Bastide et al., 1993) e Agave deserti (Nobel, 1976), sete dias de seca não afetaram a variação circadiana de malato e em Aechmea MAYA depois de 14 dias sem água o nível de acúmulo de carbono é parecido com o de plantas bem hidratadas (Ceusters et al., 2009). No experimento de Acevedo et al. (1983), depois de 15 dias de seca, a variação circadiana de acidez decresce 66\%. Durante a seca, em Aechmea MAYA, depois de 45 dias de seca, ocorre diminuição no volume da clorofila, o que causa uma diminuição na capacidade de interceptar luz (Ceusters et al., 2009). A relação entre a indisponibilidade hídrica em um curto período de tempo e o acúmulo de malato é variável em diferentes espécies de plantas CAM. Diferentes espécies respondem de diferentes maneiras ao inicio do período de seca. Para definir o comportamento de $D$. tuberosa sobre estresse hídrico foi conduzido o experimento da casa de vegetação. Os resultados obtidos na casa de vegetação estão de acordo com os dados da bibliografia para um curto período de estresse hídrico. A acidez 
titulável em folhas de $D$. tuberosa no começo da manhã decaiu logo na primeira semana, evidenciando uma reduzida capacidade de suportar um curto período de estresse hídrico sem modificar a taxa de assimilação de carbono.

Se a seca continuar, mantendo a planta em estresse hídrico, as plantas CAM diminuem sua taxa metabólica e são capazes de suportar severos períodos de estresse hídrico. Depois de prolongado período de seca os estômatos deixam de abrir durante a noite e permanecem fechados durante todo o ciclo circadiano com pequena variação na concentração de malato e acidez. Esse processo é chamado de CAM "idling". O CAM "idling" conferiria às plantas CAM grande capacidade de habitar ambientes com secas severas, mantendo assim atividade metabólica mesmo durante longos períodos de seca e capacidade de rápida recuperação com reidratação com tomada de $\mathrm{CO}_{2}$ comparável a níveis pré-estresse. (Ceusters et al., 2009). A variação na acidez do mesofilo se deve ao acúmulo noturno de malato que é sintetizado a partir do $\mathrm{CO}_{2}$ liberado pela respiração da planta. O malato, assim como o $\mathrm{CO}_{2}$ liberado pela respiração durante o dia, é utilizado no processo de fotossíntese, na presença de luz.

A manifestação de CAM "idling" é verificada em Agave deserti em 44 dias (Nobel, 1976) e em Opuntia ficus-indica em 65 dias após início da seca (Acevedo et al., 1983). Segundo Ceusters et al., (2009), com 120 dias sem hidratação apenas 2\% da carboxilação noturna ocorre. Com 140 dias sem hidratação os estômatos estão fechados o tempo todo caracterizando a ocorrência de CAM "idling" e no final de seis meses de falta de água o ADAM chega a $6 \%$ comparado com o controle. Entre as várias espécies com manifestações de CAM, o tempo necessário para apresentar alterações no ciclo de carbono e para alcançar CAM "idling" esta relacionado com o estado de hidratação preliminar da planta e outras características do ambiente, como temperatura e PAR. 
Nesse experimento não foram utilizados mecanismos de quantificar as trocas gasosas entre a folha e o ambiente, pois a anatomia da folha não permitiu o uso das câmaras foliares disponíveis devido à suculência. Desta forma não foi possível determinar diretamente se Dyckia tuberosa cessou a abertura estomática, alcançando CAM "idling", no final dos 84 dias de seca. Porém, nas semanas finais a acidez titulável no mesofilo no começo da manhã não diminuiu mantendo-se em um patamar mínimo de cerca de $100 \mu \mathrm{mol} / \mathrm{g}$. de acidez titulável. O patamar mínimo foi alcançado em 30 dias de seca nas plantas que estão em vasos com mais de uma roseta e em 60 dias de seca, em vasos com uma roseta. O valor de $100 \mu \mathrm{mol} / \mathrm{g}$ é igual nos dois grupos e pode ser característico da espécie.

Quando a chuva põe fim a um período de seca, a resistência estomatal reage prontamente ao final do estresse hídrico (Szarek \& Ting, 1974) mesmo que as chuvas ocorram sem regularidade (Nobel, 1976). Para estudar como as variáveis climáticas influenciam a acidez titulável do mesofilo ao longo do tempo tais variáveis no período de um, três e sete dias foram relacionadas, nas análises estatísticas, com os resultados da acidez titulável. Os resultados obtidos no ambiente natural do afloramento rochoso demonstram que, aparentemente, as condições ambientais das últimas 24 horas antes da coleta influenciam a acidez do mesofilo, assim com as condições ambientais das últimas 72 horas. A pluviosidade do dia anterior à coleta influenciou a acidez titulável. Contudo, a pluviosidade dos três dias anteriores exerceu maior influência na acidez titulável do mesofilo no começo da manhã. Em Opuntia basilaris, Szarek et al., (1973) descreve que depois de um dia da chuva intensa o valor máximo de acúmulo de malato no tecido aumentou $45 \%$ e em três dias depois da chuva era $200 \%$ maior em relação ao estado de desidratação, e isso pode indicar que, mesmo capaz de fazer a fixação logo após a chuva, 
alguma característica influenciaria a capacidade máxima de acumular malato, que só é alcançada três dias depois da chuva.

Para as variáveis climáticas obtidas na estação meteorológica de Atibaia, o período de maior influência sobre o comportamento fisiológico de $D$. tuberosa foi de três dias anteriores, seguido pela influência das condições climáticas no dia anterior e a menor influência por período foi a média dos sete dias anteriores à coleta. A média dos valores de RGT dos sete dias anteriores à coleta foi a única variável, nesse período, que influenciou a acidez titulável no começo da manhã. As demais variáveis climáticas ou não influenciaram, ou foram os únicos dados presentes nos resultados que não permitem inferir uma relação previsível, como a umidade relativa do ar máxima.

Os resultados para umidade relativa do ar máxima e temperatura mínima dos sete dias que precedem a coleta foram os únicos dados que não corroboraram com os demais. O aumento da umidade relativa máxima do dia anterior e dos três dias passados levou a um aumento na acidez titulável no nas amostras do começo da manhã, mas a média das umidades relativas máximas dos sete últimos dias levaram, segundo os resultados, a uma diminuição dessa acidez titulável. Altos valores de temperatura mínima no dia da coleta levaram a uma menor acidez titulável no começo da manhã, nos três dias anteriores não influenciou e nos sete dias anteriores, seguindo os dados e no sentido contrário de períodos menores de tempo para a mesma variável, levariam a um aumento da acidez titulável. Todos os outros dados, nos diferentes períodos, permitem uma interpretação linear.

A disponibilidade de luz para re-fixação diurna do $\mathrm{CO}_{2}$ influenciaria diretamente, aumentando o valor de acidez acumulada no início da manhã M2 (Acevedo et al., 1983) e, 
portanto no ADAM. Mas nos dados obtidos no afloramento rochoso, o aumento do RGT (Radiação Global Total) levou a uma diminuição na acidez titulável. O padrão inverso ao registrado por Acevedo et al. (1983) observado neste trabalho poderia ser produzido pela ocorrência de fotoinibição. É aceitável supor que no afloramento rochoso, em dias de plena luminosidade, o volume de PAR que é interceptado pela planta seja o suficiente para causar estresse fótico. Dado que uma maior intensidade da radiação global condiz com um aumento de temperatura, especialmente se não existe uma contribuição da transpiração (no caso de uma planta CAM estrita), a combinação de altas temperaturas e alta luminosidade encontrada no ambiente do afloramento rochoso poderia facilitar o estresse fótico, reduzindo o ADAM.

A temperatura foi a única variável que influenciou mais no dia da coleta do que nos três dias anteriores. Extremos de temperatura, tanto máximos como mínimos, levaram a uma menor acidez titulável no começo da manhã. Dias muito quentes geralmente são dias com alta RGT, e noites frias também estão relacionadas com alto RGT, uma vez que dias sem nuvens levam a noites sem nuvens e essas tem menor temperatura do que noites com nuvens pela perda de energia para o firmamento ser maior. Essas variáveis são altamente correlacionadas como encontrado na matriz de correlação de Spearman (tabela 9), o que pode ter influenciado no resultado, impedindo a averiguação do efeito isolado da temperatura em CAM.

Quanto mais úmido o ar, maior foi a acidez do mesofilo no começo da manhã. A umidade relativa do ar, que assim como precipitação e RGT tiveram a média dos três dias anteriores como o período de maior influencia e foi a variável ambiental que mais influenciou depois de RGT. A umidade relativa do ar foi mais importante do que a 
pluviosidade na determinação da acidez titulável do mesofilo e uma forma de a umidade relativa do ar influenciar em CAM é através da disponibilidade hídrica.

O tamanho e inclinação da ilha de vegetação e sua posição no domo de esfoliação do afloramento rochoso não exerceram influência na acidez titulável do mesofilo no começo da manhã. Se a área da ilha de vegetação influencia ou não na comunidade vegetal característica de afloramento rochoso que a ocupa ainda é um assunto controverso (Takahasi, 2011). Porém, essas variáveis afetaram a acidez titulável do mesofilo no final da tarde (M1).

As coletas no final da tarde (M1), com o sol se pondo, e outra no começo da manhã (M2), com o sol nascendo, foram realizadas com o intuito de definir a variação líquida de malato, que foi sintetizado durante a noite. Se a primeira for subtraída da segunda teremos a variação noturna líquida da acidez titulável, podendo inferir a concentração de malato que foi sintetizado durante a noite. A essa variação líquida demos o nome de ADAM.

Ao observarmos a série temporal da acidez titulável do mesofilo no final da tarde na casa de vegetação notamos que houve uma tendência de elevação da acidez titulável ao longo da seca. No grupo com uma planta por vaso a tendência é mais tardia que no grupo com duas rosetas por vaso, que apresenta essa tendência de aumento logo na primeira semana, mas os dois grupos apresentaram a tendência e por haver diferença entre os dois grupos a força do argumento de que essa elevação esta relacionada com estresse hídrico ganha força. E os dados do ambiente natural corroboram com essa interpretação. Todos os dados, com exceção dos acima citados como discrepantes, 
apresentam uma relação lógica entre eles. Os efeitos das variáveis ambientais sempre tiveram sentido contrários na acidez titulável do começo da manhã e do final da tarde.

Altos valores de pluviosidade e umidade relativa do ar diminuíram a acidez titulável no final da tarde (M1). Um baixo valor de M1 demonstra que uma maior concentração de malato foi utilizada ao longo do período com luz do dia. Se uma maior hidratação leva a uma maior concentração de malato no começo do dia e a uma menor concentração de malato no final do dia, o volume de fotossíntese que ira ocorrer é maior quando $D$. tuberosa estiver bem hidratada.

Altas temperaturas máximas e mínimas levam a uma alta acidez titulável no final da tarde. A RGT influenciou M2 muito mais do que influenciou M1. Em M1 a RGT dos sete dias anteriores à coleta influenciam, mas em períodos menores de tempo (três dias e no dia anterior) a influencia da RGT na acidez do mesofilo no final da tarde é bem menor.

As variáveis ambientais nos sete dias antes da coleta tem maior efeito do que do começo da manhã. Para M1, a precipitação e a umidade relativa máxima dos sete dias teve o maior efeito, enquanto as temperaturas influenciaram mais em três dias.

A área, a inclinação e a posição das ilhas de vegetação influenciaram a acidez titulável no final da tarde. M1 foi menor em ilhas de vegetação com menores áreas, pois o maior volume de protosolo retém água que poderá ser utilizada pela planta ao longo dos dias sem precipitação. M1 foi menor em ilhas de vegetação com maior inclinação, pois quanto mais inclinada a rocha matriz maior é a força derivada da gravidade que carreia a água para planos menos elevados. 
As ilhas de vegetação na posição noroeste teve o menor valor de M1 entre as vertentes, talvez devido à orientação de vertente e à variação de microclimas, comum em afloramentos rochosos. A face noroeste recebe radiação solar, o que pode ser um diferencial positivo para $D$. tuberosa, seja para seus padrões fisiológicos ou para a competição com outras plantas do afloramento rochoso, que, embora sejam adaptadas ao ambiente e capazes de resistir ao estresse fótico, nenhuma é CAM, uma vez que $D$. tuberosa é a única planta CAM do afloramento rochoso Pedra Grande (Meirelles, 1996). Assim como a alta radiação solar, a diversidade de microclimas também é uma característica de afloramentos rochosos. Diferentes microclimas podem afetar de forma diferente CAM e uma definição ainda mais precisa das características de cada ilha de vegetação se faz necessária para permitir a construção de uma relação entre a diversidade de microclimas e a variação, entre as ilhas, da acidez titulável no final da tarde. A variação pode ter sido motivada pela localização da ilha de vegetação no domo da Pedra Grande e pela diversidade de microclimas.

A indisponibilidade de água diminuiu a capacidade da planta de concentrar malato durante a noite levando a uma menor disponibilidade de $\mathrm{CO}_{2}$ para fotossíntese ao longo do dia. O malato no começo da manhã (M2) é menor sob estresse hídrico, pois a taxa de fotossíntese em $D$. tuberosa ao longo de um dia deve ser menor. A taxa de fotossíntese é afetada pela concentração de malato no começo da manhã, mas também é afetada, em menor parte, pela concentração de malato no final da tarde (M1), que aumenta ao longo da seca. A interação entre M1 e M2 ao longo da seca leva a uma diminuição da amplitude diária de acúmulo de malato (ADAM) maior do que o efeito isolado de M2.

Quando a planta tinha acesso à água, a acidez titulável durante a manhã (M2) era 10 vezes maior do que aquela verificada nas folhas à tarde (M2/M1 10$)$. Na condição de 
déficit mais intenso por 60 dias, o valor da acidez titulável à tarde era por volta da metade do valor verificado de manhã (M2/M1 2). Se os valores de acidez titulável à tarde não variassem ao longo do tempo nas plantas sem acesso à água, a razão M2/M1 seria aproximadamente 4, o dobro da observada. Essa observação torna-se mais relevante se for levado em conta que M2 alcançou um patamar mínimo, mas M1 não alcançou um patamar, sugerindo que caso a seca se prolongue, a acidez titulável no final da tarde pode aumentar ainda mais, diminuindo o ADAM e incrementando o efeito de apresentar uma alta concentração de ácidos tituláveis. Portanto, a importância do aumento de M1 sob condição de estresse hídrico foi evidente.

Luttge (1986) buscando justificar os padrões de ocupação frente às características fisiológicas das plantas CAM, propõe que nas últimas horas de escuro na floresta tropical a umidade relativa do ar e os níveis de malato dentro da folha alcançam seus valores máximos levando a uma aquisição extra de água, uma vez que o malato é osmoticamente ativo. Ao longo do dia, quando o malato é utilizado na fotossíntese, esta água seria liberada no mesófilo da folha e estaria disponível para ser usada pelo metabolismo celular.

A partir de dados desse trabalho podemos inferir que a condição de hidratação de D. tuberosa não depende somente da disponibilidade hídrica através da chuva. Uma outra característica climática, a umidade relativa do ar, pode ser responsável pela condição de hidratação da planta. Se for verdade que o malato tem a capacidade de interceptar vapor de água da atmosfera durante a noite, transferindo-o para o interior da planta, tornando essa água disponível para seu metabolismo quando o malato é descarboxilado, então é justificável supor que o aumento da acidez titulável no final da tarde ao longo da seca aumenta a efetividade dessa captura de vapor de água atmosférico, principalmente no começo da noite, uma vez que, uma alta acidez no começo da noite, caracterizada pela 
planta sobre estresse hídrico, permite que o volume de água interceptado ao longo de todo o período sem luz seja maior quando comparado com uma modelo CAM hipotético onde a concentração de malato no final da tarde seja independente da condição hídrica da planta. Um ponto que merece atenção é o patamar mínimo que foi alcançado por M2, mas não foi alcançado por M1.

Para determinar os efeitos da umidade relativa do ar em $D$. tuberosa experimentos com essa variável devem ser realizados em situações controladas. A capacidade de se hidratar a partir de vapor de água atmosférico é um ponto fundamental no entendimento de como as plantas CAM se comportam frente às adversidades e potencialidades ambientais e pode trazer luz à discussão das justificativas que levam essas plantas a ocupar ambientes de baixa disponibilidade hídrica, tanto em climas áridos, como em habitats epifíticos. 


\section{CONCLUSÃO E CONSIDERAÇÕES FINAIS}

Os padrões de variação na acidez titulável em D. tuberosa respondem à disponibilidade de água nas condições semi-controladas da casa de vegetação.

Os resultados desse trabalho foram interpretados a partir de uma possível relação entre a obtenção de água e a umidade relativa do $\operatorname{ar}$ em $D$. tuberosa. Os indícios poderiam ser testados através de outros delineamentos experimentais para testar essa hipótese. Entre estes, experimentos em ambientes controlados com outras características ambientais como temperatura e intensidade de PAR fixas em ambientes com diferentes umidades relativas do ar. Essa relação deve ser demonstrada levando em conta o comportamento da acidez no final da tarde em situação de estresse hídrico, uma vez que aparentemente a acidez titulável no final da tarde é maior quanto maior for o estresse hídrico. 


\section{Referências}

Acevedo E.; Badilla I; \& Nobel P.S. 1983. Water Relations, Diurnal Acidity Changes, and Productivity of a Cultivated Cactus, Opuntia ficus-indica. Plant Physiol. 72: 775-780.

Almeida, F.F.M. de; Hasui, Y.; Ponçano, W.L.; Dantas, A.S.L.; Carneiro, C.D.R.; Melo, M.S. de. \& Bistrichi, C.A. 1981. Nota Explicativa do Mapa Geológico do Estado de São Paulo. São Paulo, IPT. 126p. (IPT, Monografias 6).

Bastide B.; Sipes D.; Hann J. \& Ting IP. 1993. Effect of severe water stress on aspects of Crassulacean acid metabolism in Xerosicyos. Plant Physiol. 103: 1089-1096.

Bender, M.M. 1968. Mass spectrometric studies of carbon 13 variations in corn and other grasses. Radiocarbon. 10: 468-472.

Black, C.C. JR. 1973. Photosynthetic carbon fixation in relation to net CO2 uptake. Annu. Rev. Plant Physiol. 24: 253-286

Borland, A.M.; Griffiths, H.; Broadmeadow, M.S.J.; Fordham, M.C. \& Maxwell, C. 1993. Short-term changes in carbon-isotope discrimination in the C3-CAM intermediate Clusia minor L. growing in Trinidad. Oecologia 95: 444-453.

Borland, A.M. \& Griffiths, H. 1996. Variation in phases of crassulacean acid metabolism and regulation of carboxylation patterns determined by carbon-isotope-discrimination techniques. In: Winter K, Smith JAC, eds. Crassulacean acid metabolism. Berlin: Springer, 230-249.

Carneiro, C.D.R. \& Souza, J.J. 2003. Mapeamento geomorfológico em escala de semidetalhe da região de Jundiaí-Atibaia. Revista Brasileira de Geomorfologia 4(2): 1730.

Cacalcante, I.N., Santiago, M.M.F. \& Rebouças, A.C. 1998. Hidroquímica dos Sistemas Aquíferos Manto de Intemperismo e Meio Fraturado na Região de Atibaia, Estado de São Paulo. Revista de Geologia 11: 31-39. 
Ceusters, J.; Borland, A.M.; Londers, E.; Verdoodt, V.; Godts, C. \& De Proft, M.P. 2009. Differential usage of storage carbohydrates in the CAM bromeliad Aechmea 'Maya' during acclimation to drought and recovery from dehydration. Physiologia Plantarum. 135: $174-184$.

Chen, L.; Lin, Q. \& Nos, A. 2002. A comparative study on diurnal changes in metabolite levels in the leaves of three crassulacean acid metabolism (CAM) species, Ananas comosus, Kalanchoë daigremontiana and K. pinnata. J. Exp. Bot. 53 (367): 341-350.

Cockburn, W.; Goh, C. J. \& Avadhani, P. N. 1985. Photosynthetic Carbon Assimilation in a Shootless Orchid, Chiloschista usneoides (DON) LDL. A Variant on Crassulacean Acid Metabolism. Plant Physiol.; 77(1): 83-86.

Coutinho, L.M. 1965. Algumas informações sobre a capacidade rithmica diaria de fixação e acumulação de $\mathrm{CO}_{2}$ no escuro em epífitas e herbaceas terrestres da mata pluvial. Botanica. 21: 395-408.

Crayn, D.M.; Winter, K.; Andrew, J. \& Smith C. 2004. Multiple origins of crassulacean acid metabolism and the epiphytic habit in the Neotropical family Bromeliaceae. PNAS. 101 (10): 3703-3708.

Cushman, J.C. \& Bohnert, H.J. 1997. Molecular genetics of crassulacean metabolism. Plant Physiol. 113: 667-676.

Goldstein, G.; Ortega J.E.; Nerd A. \& Nobel P.S. 1991. Diel patterns of water potential components for the crassulacean acid metabolism plant Opuntia ficus-indica when wellwatered or droughted. Plant Physiology 95: 274-280.

Hanscom, Z. III \& Ting I.P. 1978. Responses of succulents to plant water stress. Plant Physiol. 61: 327-330.

Holtum J.A.M.; Winter, K.; Weeks M.A. \& Sexton T.R. 2007. Crassulacean acid metabolism in the ZZ plant, Zamioculcas zamiifolia (Araceae). Am J Bot 94: 1670-1676. 
Kornas, A.; Fischer-Schliebs, E.; Luttge, U. \&, Miszalski, Z. 2009. Adaptation of the obligate CAM plant Clusia alata to light stress: Metabolic responses. Journal of Plant Physiology 166, (17): 1914-1922.

Lee H.S.J.; Luttge U.; Medina E.; Smith J.A.C.; Cram W.J.; Diaz M.; Grifiths H.; Popp M.; Schafer C.; Stimmel K-H. \& Thonke B. 1989.Ecophysiology of xerophytic and halophytic vegetation of a coastal alluvial plain in northern Venezuela. III. Bromelia humilis Jacq. A terrestrial CAM bromeliad. New Phytologist. 111: 253-271.

Luttge, U. 1986. Nocturnal water storage in plants having crassulacean acid metabolism. Planta 168: 287-289.

Luttge, U. 1987. Carbon dioxide and water demand. Crassulacean acid metabolism (CAM). A versatile ecological adaptation exemplifying the need for integration in ecophysiological work. New Phytol. 106: 593-629

Luttge, U. 1989. Vascular epiphytes: Setting the scene. In: LuÈttge U, ed. Vascular plants as epiphytes. Evolution and ecophysiology. Ecological Studies vol 76. Berlin, Heidelberg, New York: Springer-Verlag, 1-14.

Luttge, U.; Pfeifer, T. ; Fischer-Schliebs, E. \& Ratajczak, R. 2000. The role of vacuolar malate-transport capacity in crassulacean acid metabolism and nitrate nutrition. Higher malate-transport capacity in the ice plant after crassulacean acid metabolis-induction and in tobacco under nitrate nutrition. Plant Physiology. 124: 1335-1347.

Luttge, U. 2002. $\mathrm{CO}_{2}$-concentratring : consequences in crassulacean acid metabolism. J. Exp. Bot. 53(378) : 2131-2142.

Luttge, U. 2004. Ecophysiology of Crassulacean Acid Metabolism (CAM). Annals of Botany. 93: 629-652.

Luttge, U. 2007. Clusia: a woody neotropical genus of remarkable plasticity and diversity. Ecological studies, vol. 194. Heidelberg- New York: Springer. 
Martin, C.E \& Jackson J.L. 1986. Photosynthetic pathways in a midwestern rock outcrop succulent Sedumn nuttallianumn Raf. (Crassulaceae). Photosynth Res. 8: 17-29.

Martin C.E.; Higley M. \& Wang W.Z. 1988. Ecophysiological Significance of C02-Recycling via Crassulacean Acid Metabolism in Talinum calycinum Engelm. (Portulacaceae). Plant Physiol. 86: 562-568.

Mattos de E.A. \& Luttge U. 2001. Chlorophyll fluorescence and organic acid oscillations during transition from CAM to C3-photosynthesis in Clusia minor L. (Clusiaceae). Annals of Botany. 88: 457-463.

Medina, B.M.O., Ribeiro, K.T. \& SCARANO, F.R. 2006. Plant-Plant and Plant-Topography Interactions on a Rock Outcrop at High Altitude in Southeastern Brazil. Biotropica 38(1): 27-34.

Meirelles, S.T. 1996. Estrutura da comunidade e características funcionais dos componentes da vegetação de um afloramento rochoso em Atibaia - SP. Tese (Doutorado em Ecologia e Recursos Naturais) -Universidade Federal de São Carlos, São Carlos, São Paulo. 270p.

Meirelles, S.T.; Mattos, E.A. \& da Silva, A.C. 1997. Potential desiccation tolerant vascular plants from southeastern Brazil. Polish J. Environ. Studies 6: 17-21.

Meirelles, S.T., PivelloR.V. \& Joly, C.A. 1999. The vegetation of granite rock outcrops in Rio de Janeiro, Brazil, and the need for its protection. Environmental Conservation 26 (1): $10-20$.

Minitab. 2003. Minitab statistical software. Release 14 for Windows. State College PA. USA.

Nobel, P.S. 1976. Water Relations and Photosynthesis of a Desert CAM Plant, Agave deserti. Plant Physiol. 58: 576-582.

Ong, B.L,; Kluge, M.; Friemert, V. 1986. Crassulacean acid metabolism in the epiphytic ferns Drymoglossum piloselloides and Pyrrosia longifolia: studies on responses to environmental signals Plant, Cell \& Environment, Blackwell Publishing Ltd 1365-3040 
Osmond, C.B. 1978. Crassulacean acid metabolism: a curiosity in context. Annu Rev Plant Physiol. 29: 379-414.

Pearson, P.N. \& Palmer, M.R. 2000. Atmospheric carbon dioxide concentrations over the past 60 million years. Nature. 406: 695-699.

Pierce, S, Winter, K. \& Grifiths H. 2002. The role of CAM in high rainfall cloud forests: an in situ comparison of photosynthetic pathways in Bromeliaceae. Plant, Cell and Environment. 25: 1181-1189.

Porembski, S. \& Barthlott, W. 2000 Granitic and gneissic outcrops (inselbergs) as centers of diversity for desiccation-tolerant vascular plants. Plant Ecology 151: 19-28.

Porembski, S. Tropical inselbergs: habitat types, adaptive strategies and diversity patterns. Rev. bras. Bot. [online]. 2007, vol.30, n.4, pp. 579-586. ISSN 0100-8404.

Reinert, F.; Russo, C.A.M. \& Salles, L.O. 2003. The evolution of CAM in the subfamily Pitcairnioideae (Bromeliaceae). Bio. J. Linnean Society. 80: 261-268.

Schmidt, J.E \& Kaiser, W.M. 1987. Response of the succulent leaves of Peperomia magnoliaefolia to dehydration. Water relations and solute movement in chlorenchyma and hydrenchyma. Plant Physiology 83: 190-194.

Schulte, P.J. \& Nobel, P.S. 1989. Responses of a CAM plant to drought and rainfall: capacitance and osmotic pressure influences on water movement. Journal of Experimental Botany 40: 61-70.

Szarek, S.R.; Johnson, H.B. \& Ting, I.P. 1973. Drought Adaptation in Opuntia basilaris. Plant Physiol. 52: 539-541.

Szarek, S.R. \& Ting, I.P. 1974. Seasonal Patterns of Acid Metabolism and Gas Exchange in Opuntia basilaris. Plant Physiol. 54: 76-81.

Takahasi, A. 2011. Ecologia da vegetação em bancadas lateriticas em Corumbá, MS. Tese (Doutorado) -Universidade de São Paulo, São Paulo. 255 pags 
Taybi, T., Nimmo, H.G. \& Borland, A.M. 2004. Expression of Phosphoenolpyruvate Carboxylase and Phosphoenolpyruvate Carboxylase Kinase Genes. Implications for Genotypic Capacity and Phenotypic Plasticity in the Expression of Crassulacean Acid Metabolism. Plant Physiology. 135: 587-598.

Tissue, D.T.; Yakir, D. \& Nobel, P.S. 1991. Diel water movement between parenchyma and chlorenchyma of two desert CAM plants under dry and wet conditions. Plant, Cell and Environment 14: 407-413.

Vesta, M.; Herppich, W.B. \& von Willert, D.J. 2001. Variability of CAM in leaf-deciduous succulents from the Succulent Karoo (South Africa). Basic and Applied Ecology. 2: 283288.

Whelan, T.; Sackett, W.M. \& Benedict, C.R. 1973. Enzymatic fractionation of carbon isotopes by phosphoenolpyruvate carboxylase from C4 plants. Plant Physiol. 51: 10511054.

Williams, E.L.Mc. 1970. Comparative Rates of Dark CO2 Uptake and Acidification in the Bromeliaceae, Orchidaceae, and Euphorbiaceae. Botanical Gazette. 131 (4): 285-290.

Winter, K.; Luttge, U.; Winter, E. \& Troughton, J.H. 1978. Seasonal Shift from $C_{3}$ Photosynthesis to Crassulacean Acid Metabolism in Mesembryanthemum crystallinum Growing in Its Natural Environment. Oecologia. 34 (2): 225-237.

Winter, K. 1980. Carbon Dioxide and Water Vapor Exchange in the Crassulacean Acid Metabolism Plant Kalanchoe pinnata during a Prolonged Light Period. Plant Physiol. 66: 917-921.

Winter, K. \& Smith, J.A.C. 1996. Taxonomic distribution of Crassulacean acid metabolism. In: Winter K, Smith JAC, eds. Crassulacean acid metabolism. Biochemistry, ecophysiology and evolution. Berlin: Springer-Verlag, 1-13.

Winter, K. \& Holtum, J.A.M. 2002. How Closely Do the $\delta 13 \mathrm{C}$ Values of Crassulacean Acid Metabolism Plants Reflect the Proportion of CO2 Fixed during Day and Night? Plant Physiology. 129: 1843-1851. 